\title{
Safety of Lithium-ion Cells at Different States of Charge
}

\author{
Judith Jeevarajan, Ph.D. \\ NASA-JSC \\ and \\ Joe Orieukwu \\ Jacobs Technology/NASA-JSC
}




\section{Introduction}

- NASA-JSC's state-of-the-art cell surveillance program

- Tested Cells (79 of each type)

\begin{tabular}{|l|c|}
\hline Manufacturer & LG \\
\hline Nominal capacity (Ah) & 3 \\
\hline Charge voltage (V) & 4.2 \\
\hline Discharge termination voltage (V) & 3.0 \\
\hline Chemistry & Lithium-ion \\
\hline Type & pouch \\
\hline Height $(\mathrm{mm})$ & 70.1 \\
\hline Width $(\mathrm{mm})$ & 68.6 \\
\hline Thickness $(\mathrm{mm})$ & 5.03 \\
\hline Mass (g) & $52.5+/-2.0$ \\
\hline
\end{tabular}

LG Li-ion Polymer/ Pouch

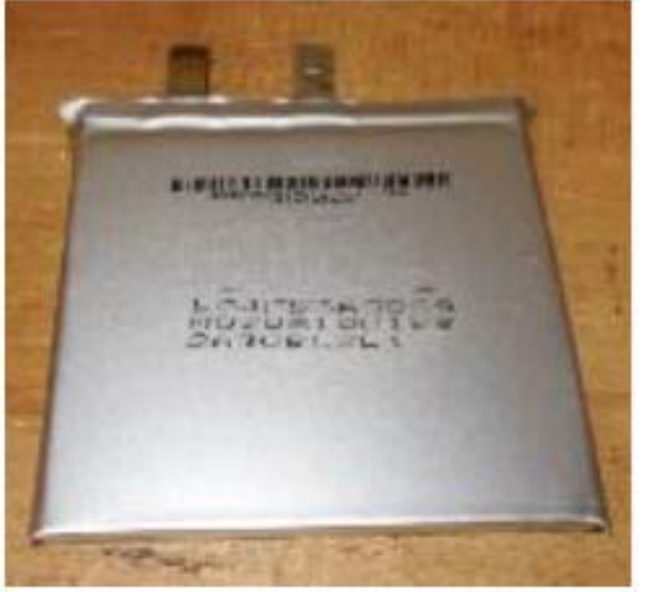

LG Li-ion 18650

Cell Info

Dimensions: $18 \mathrm{~mm}$ diam; $65 \mathrm{~mm}$ height

Voltage: $4.35 \pm 1 \%-3.0 \mathrm{~V}$

Capacity (C): $3.0 \mathrm{Ah}$

Mass: $48.5 \pm 2.0 \mathrm{~g}$

Cells Tabbed: No

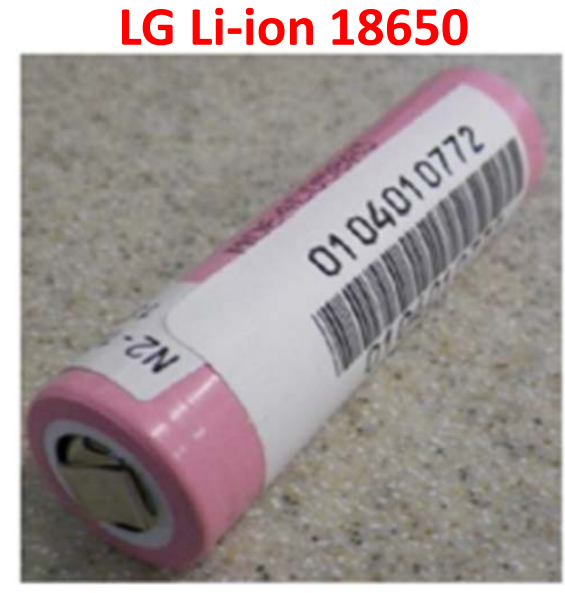




\section{Initial Charge/Discharge Characteristics}

- All cells were cycled using a $C / 5$ rate of charge and discharge;

- EOCV for Li-ion pouch is $4.2 \mathrm{~V}$ and $4.35 \mathrm{~V}$ for Li-ion 18650 cells

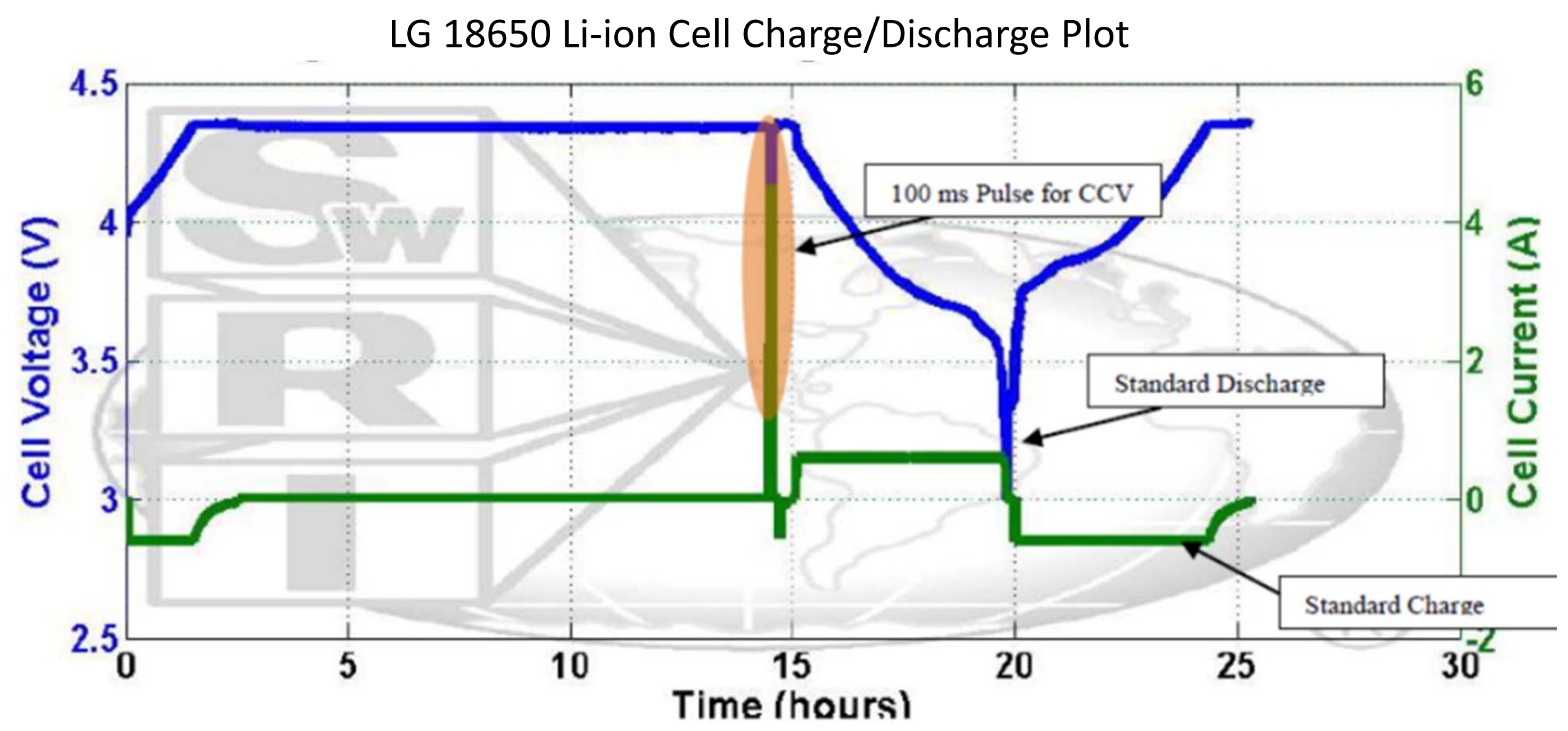




\section{Overcharge Test (3A Charge Current)}

$12 \mathrm{~V}$ limit; maximum overcharge time - 6 hours

Li-ion Pouch
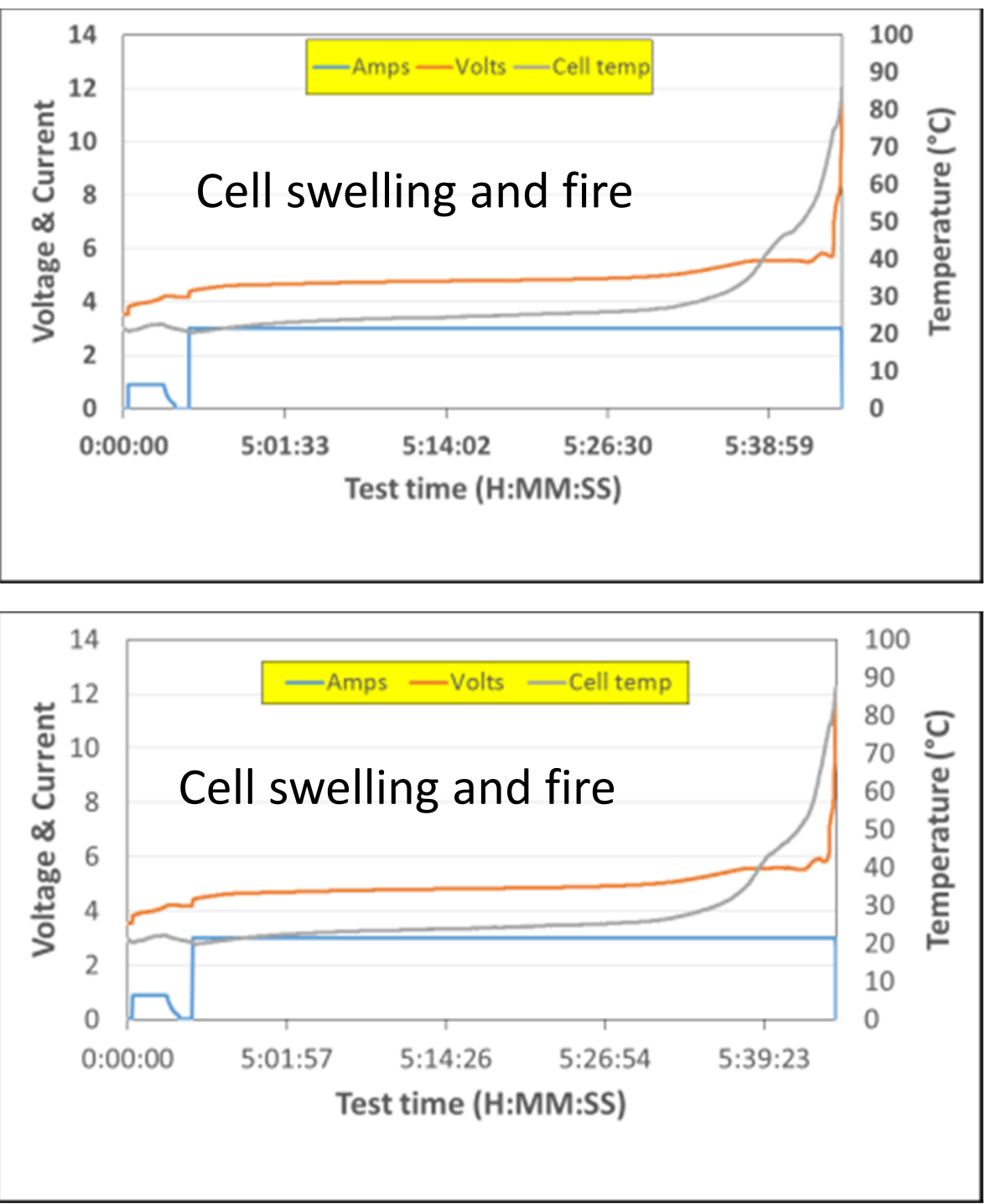

Li-ion 18650

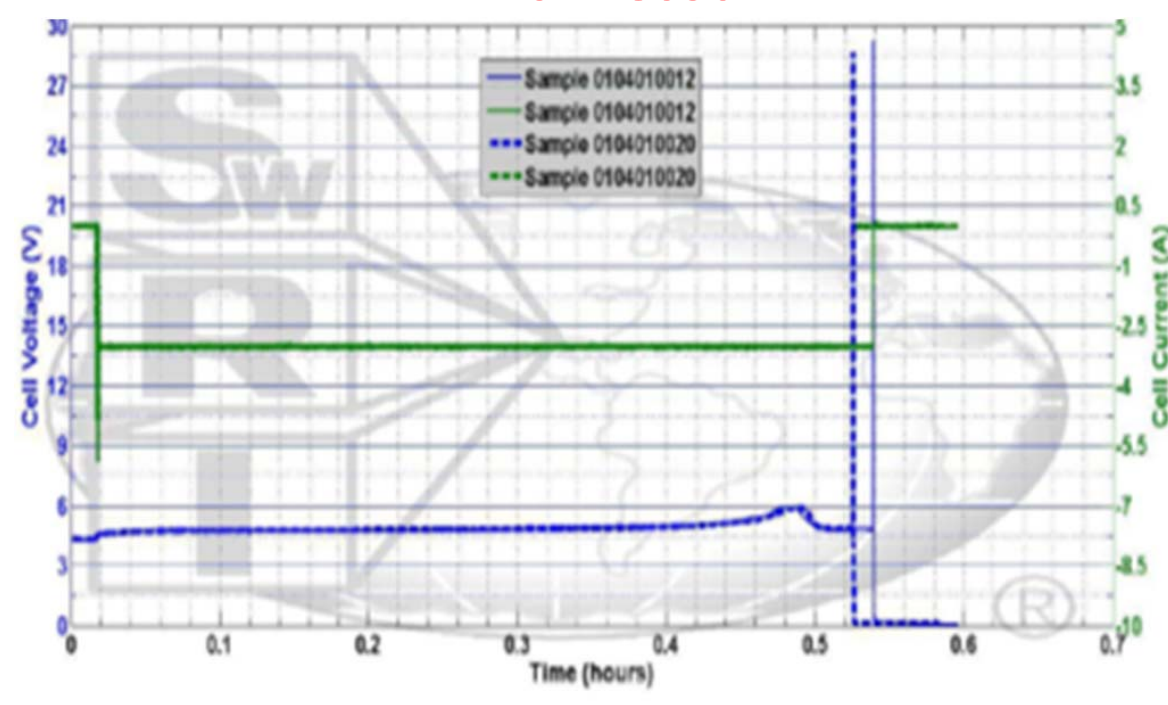

CID Activation

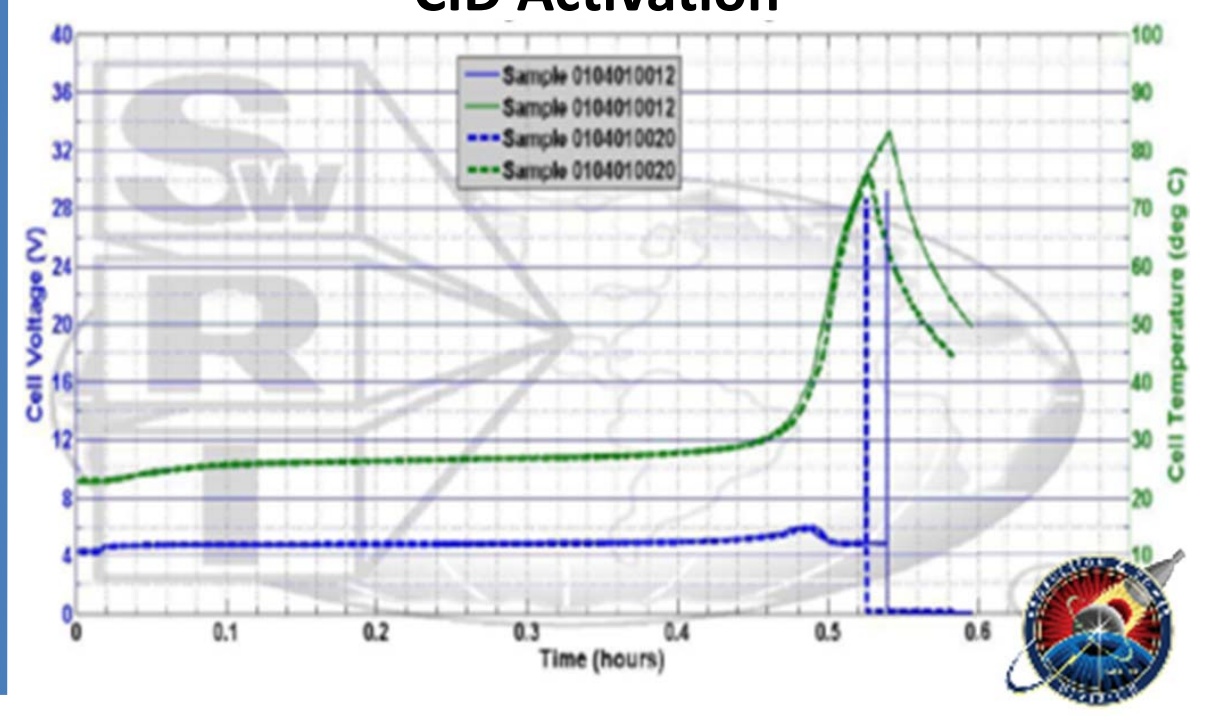




\section{Overcharge Test (1.5A Charge current)}

$12 \mathrm{~V}$ limit; maximum overcharge time - 6 hours
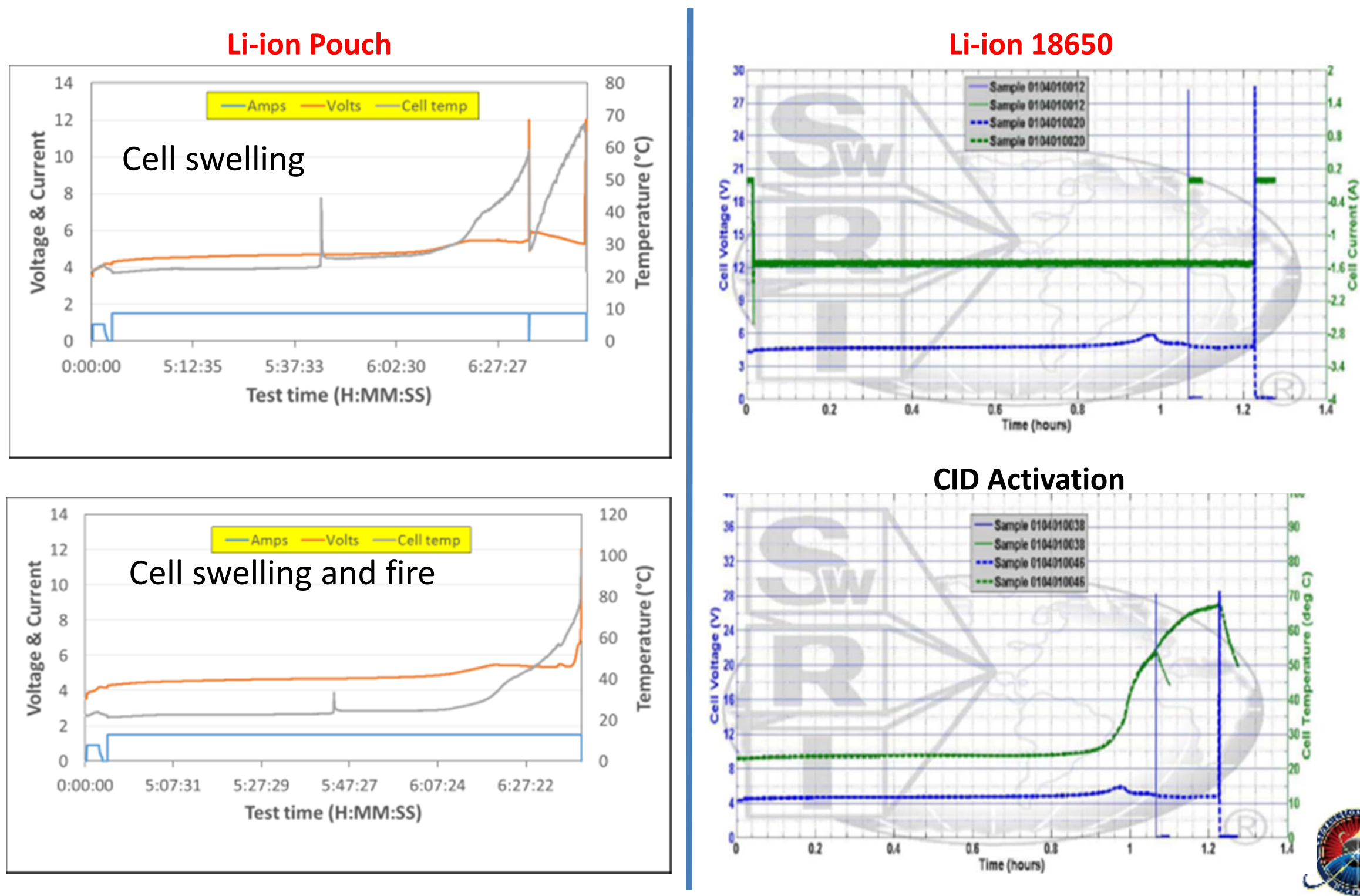


\section{Overcharge Test Photos}
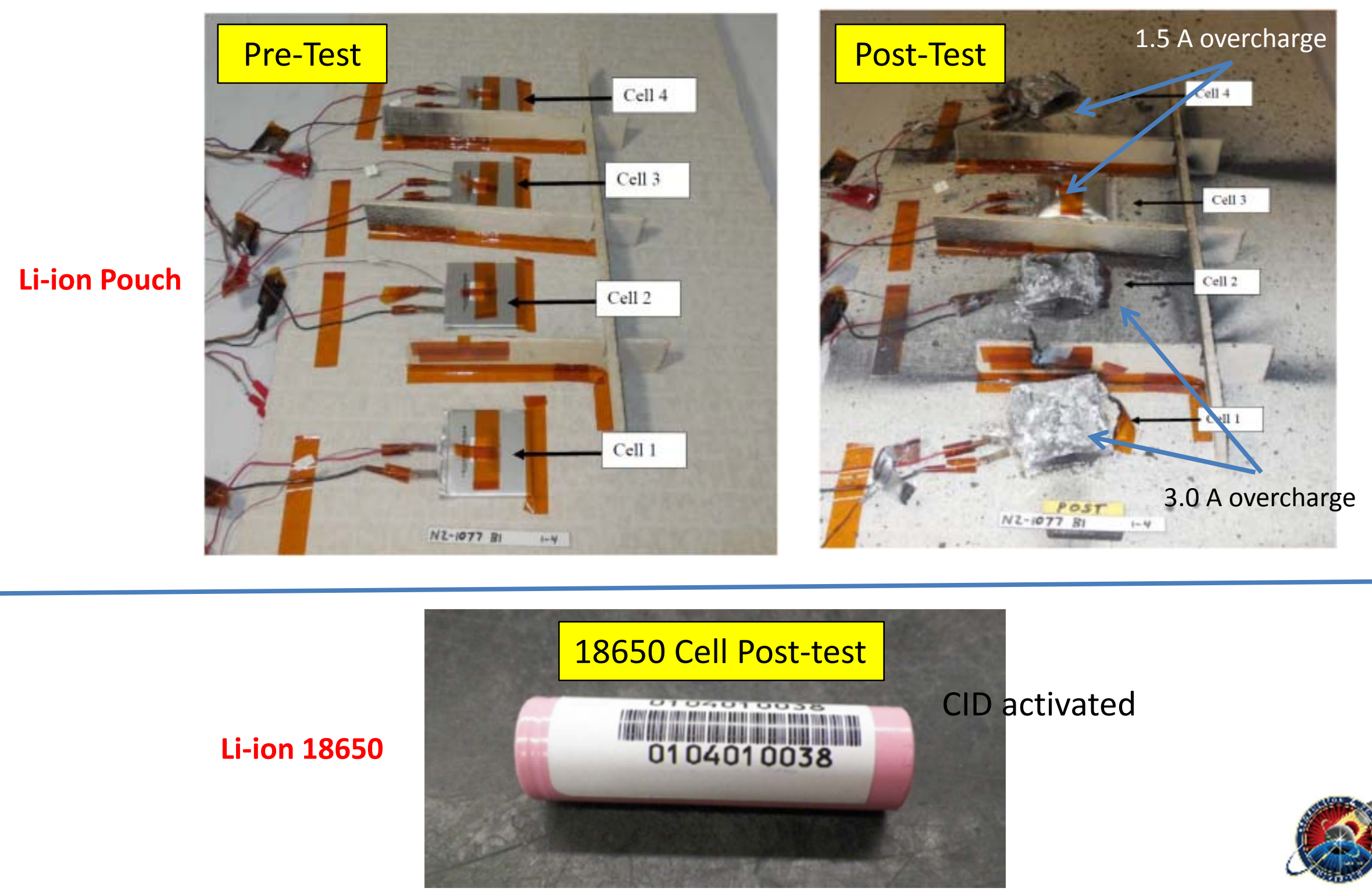

J. Jeevarajan, Ph.D./ NASA-JSC

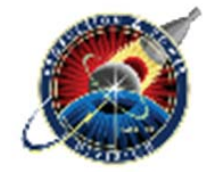




\section{Overcharge Test}

\section{$12 \mathrm{~V}$ limit; maximum overcharge time - 6 hours}
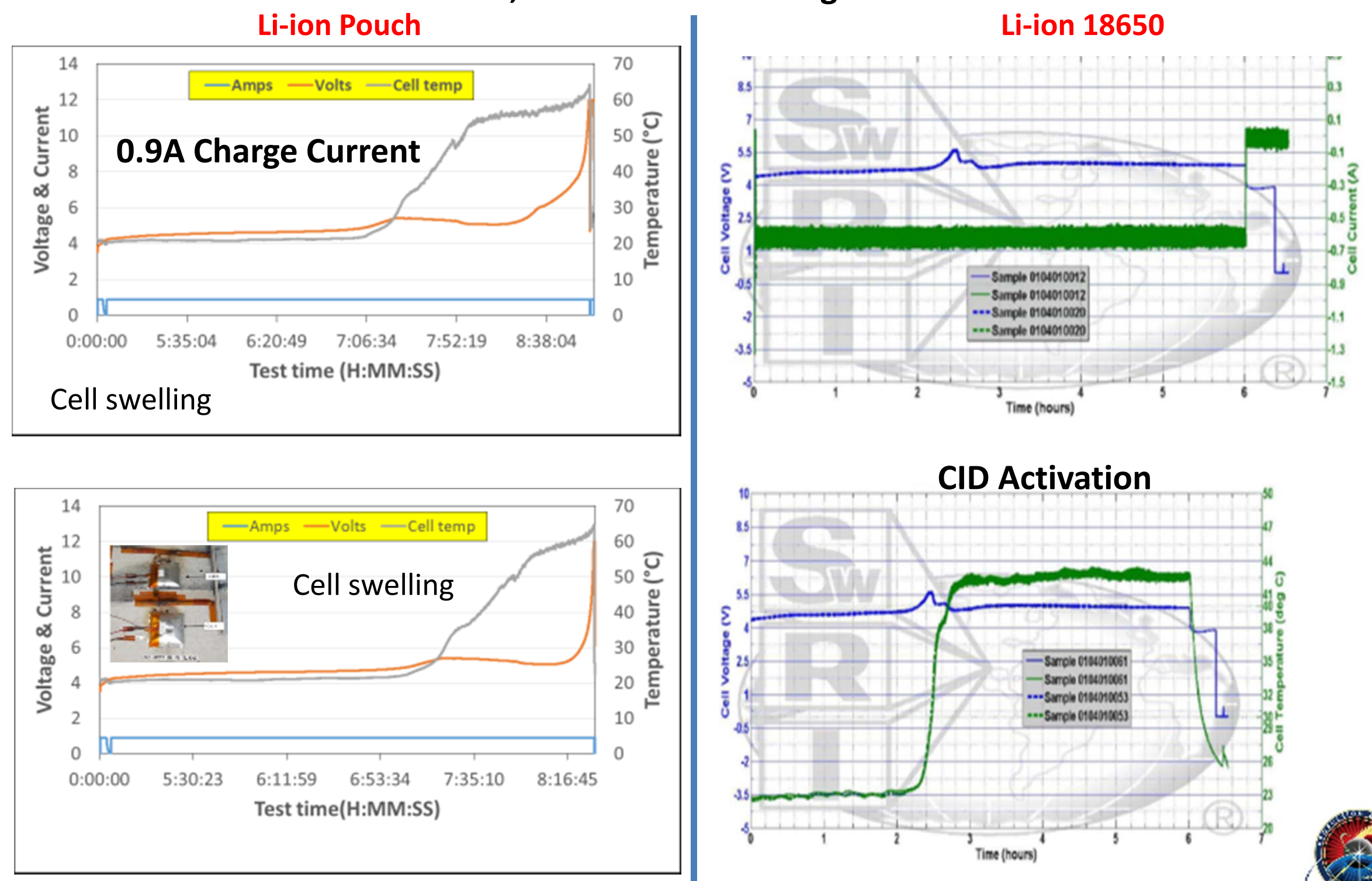


\section{S String Overcharge}

Li-ion Pouch

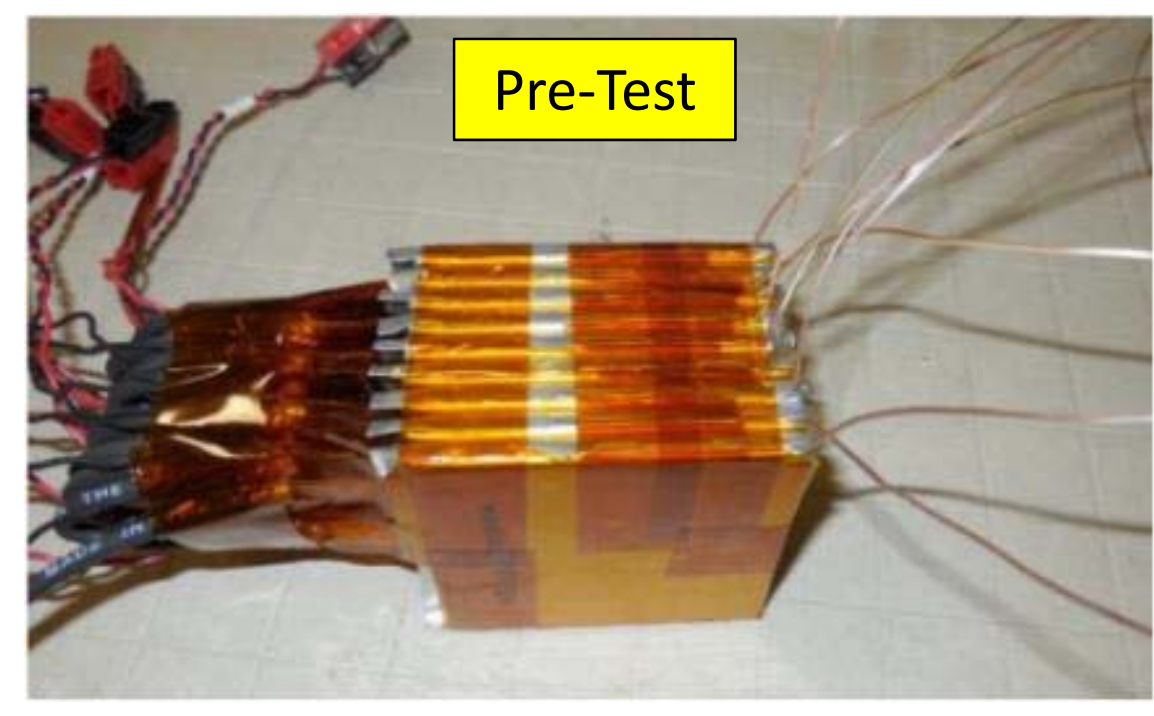

(0.9 A Charge Current to $64 \mathrm{~V}$ limit); 6 hours max

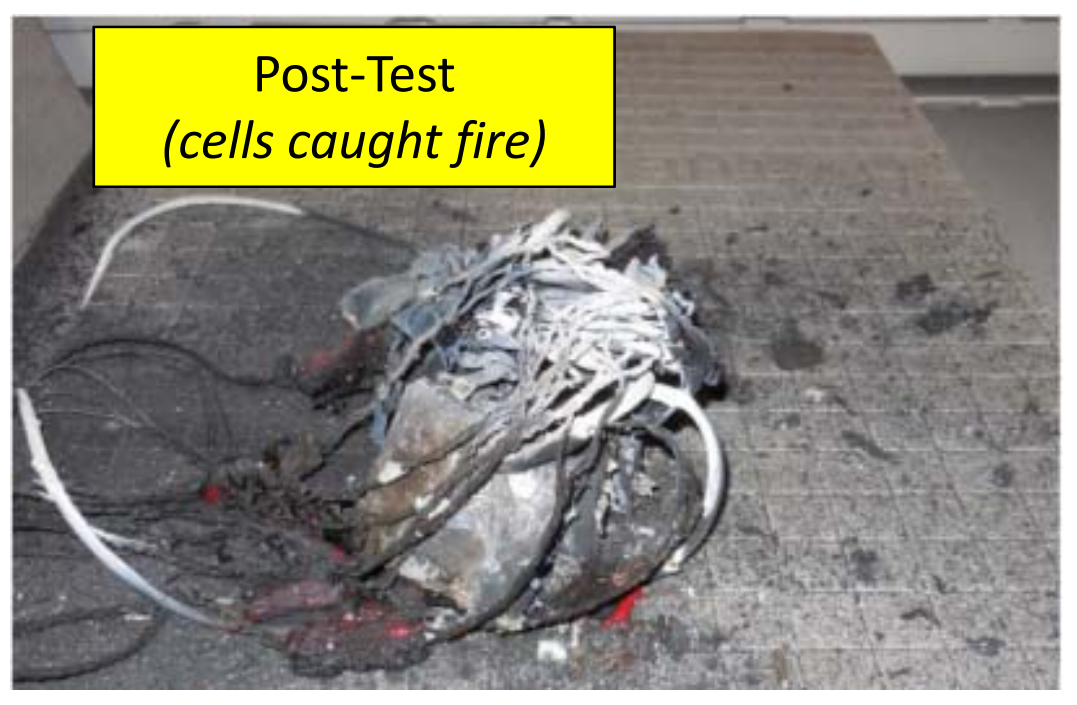

(3 A Charge Current to 64 V limit); 6 hours max

Li-ion 18650

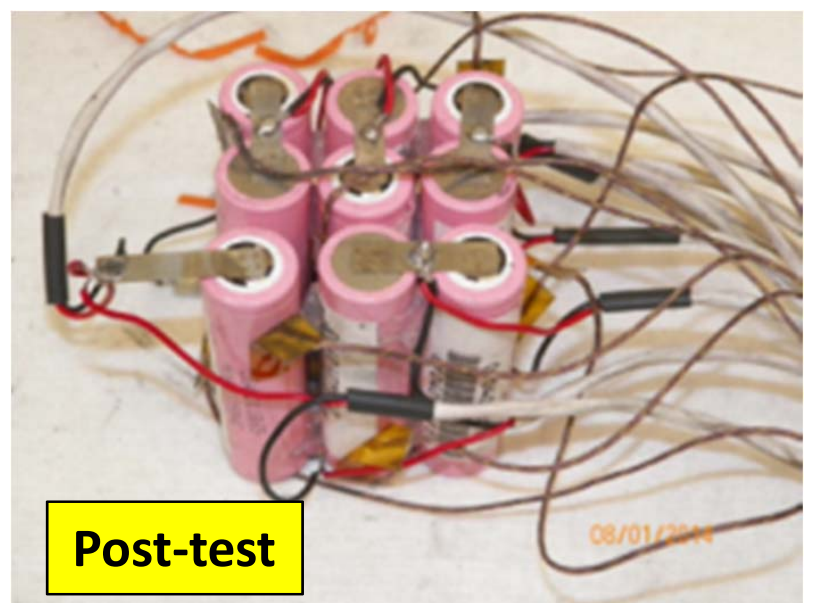

J. Jeevarajan, Ph.D./ NASA-JSC 


\section{S String Overcharge Test}

\section{Li-ion Pouch}

(0.9 A Charge Current to 64 V limit); 6 hours max
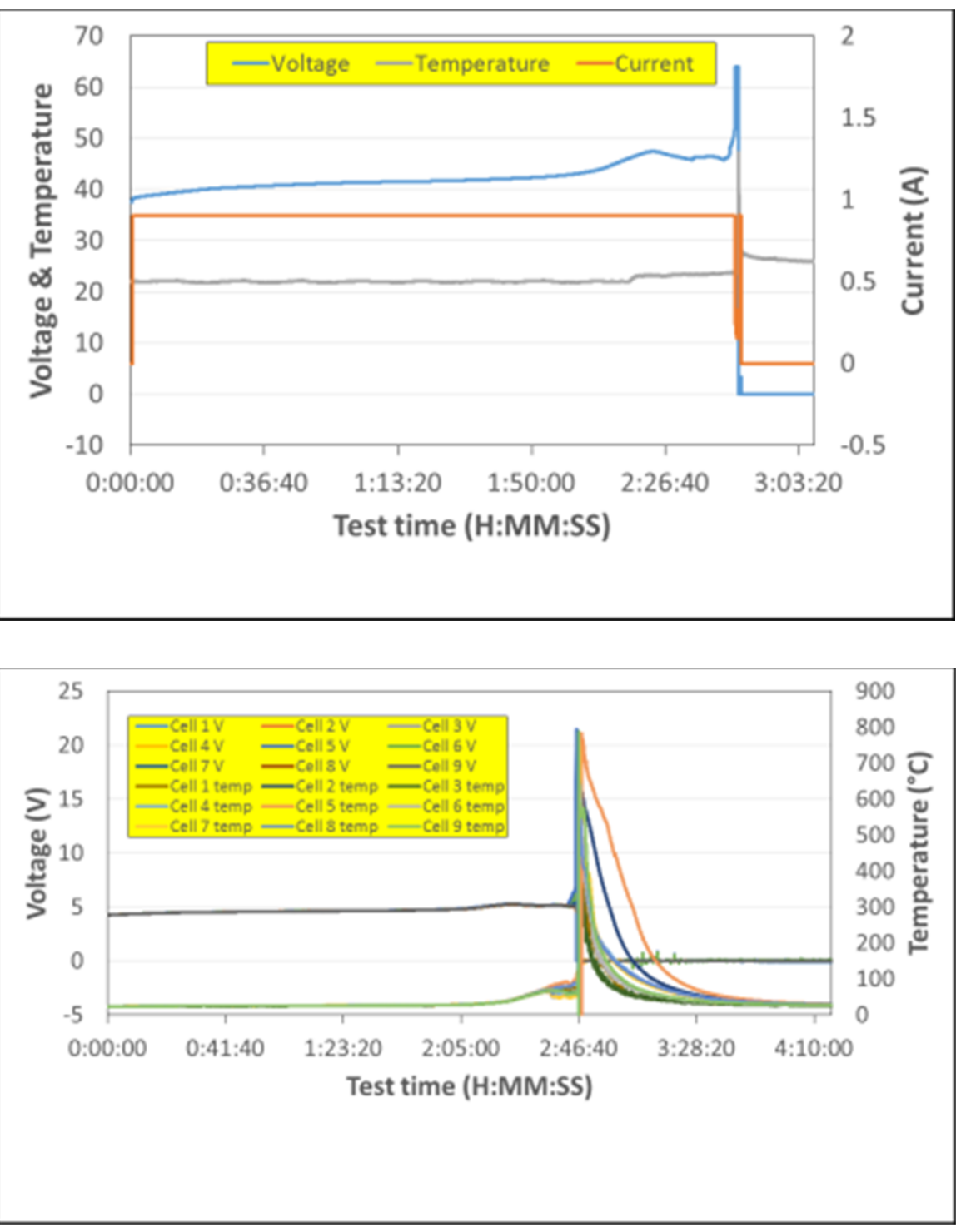

Li-ion 18650

(3 A Charge Current to $64 \mathrm{~V}$ limit); 6 hours max
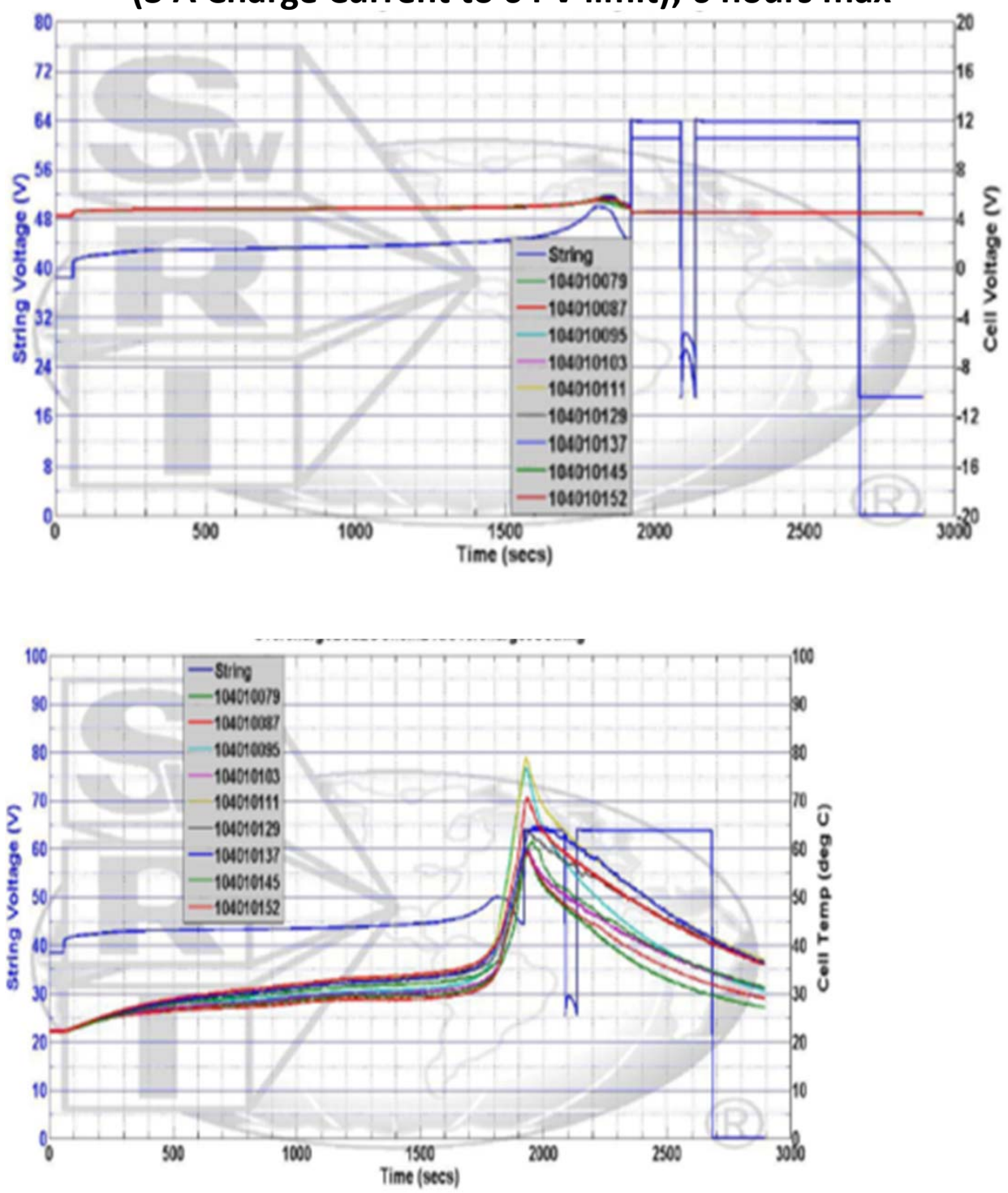


\section{P Bank Overcharge}

(7.2 A Charge Current to $64 \mathrm{~V}$ limit); 6 hours max

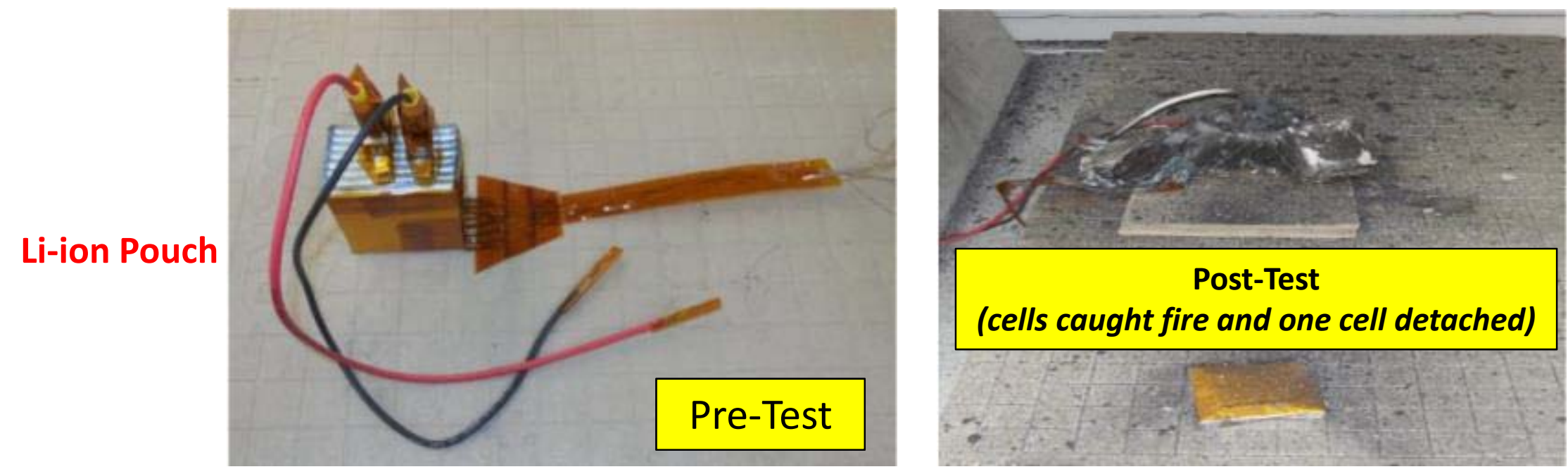

Li-ion 18650
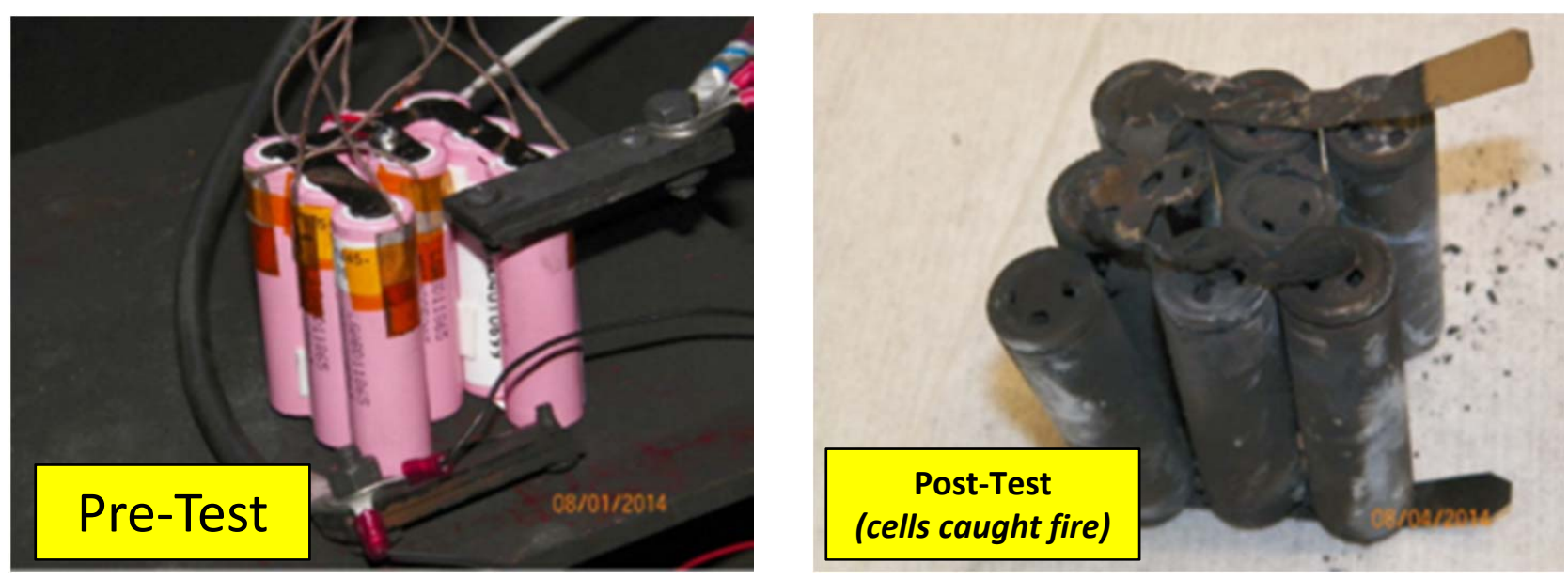


\section{P Bank Overcharge}

Li-ion Pouch

\section{(7.2 A Charge Current to $64 \mathrm{~V}$ limit); 6 hours max}
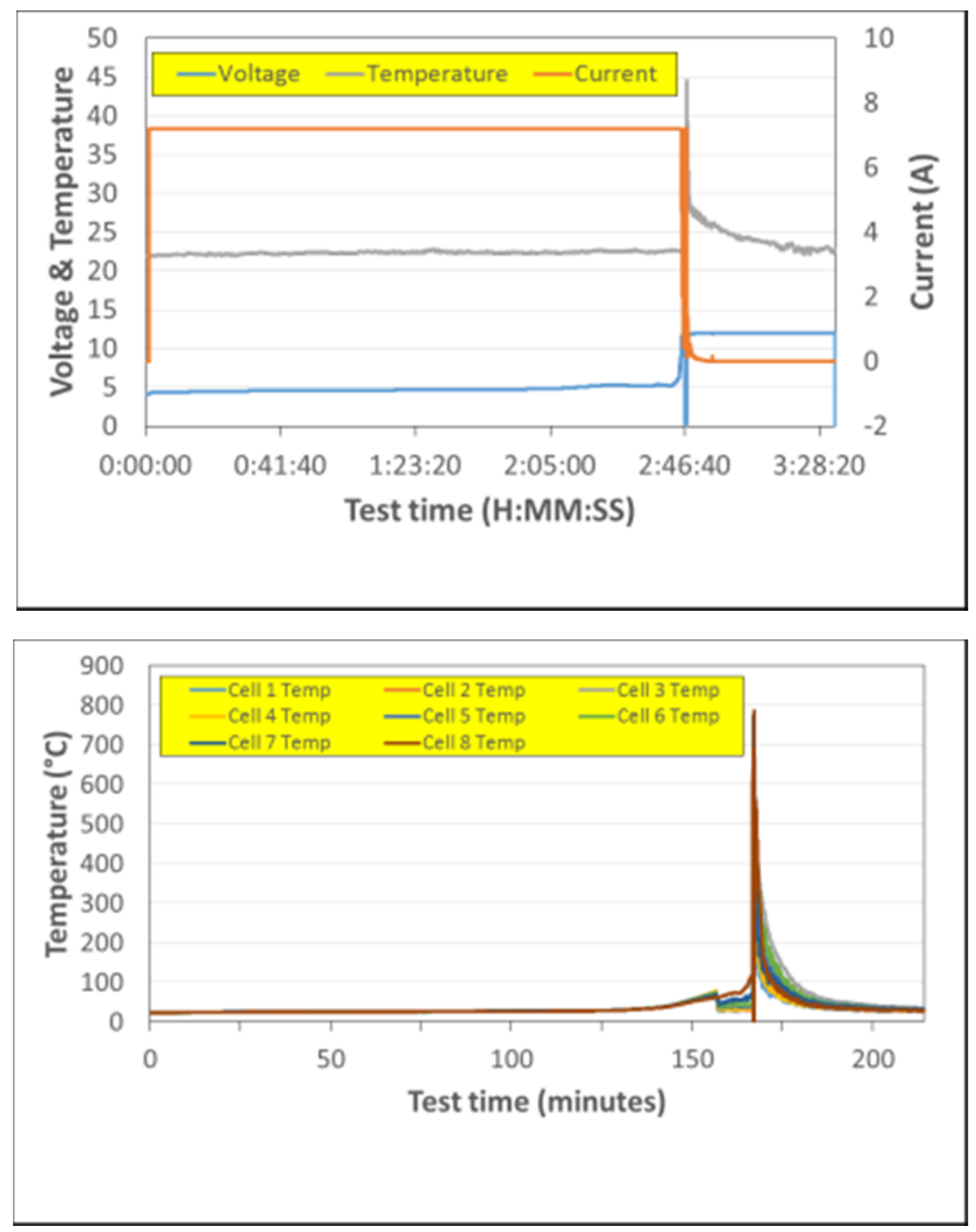

Li-ion 18650

(24 A Charge Current to $64 \mathrm{~V}$ limit); 6 hours max OrerchargeB 1 eLCCMemB1eOverchargetPstring

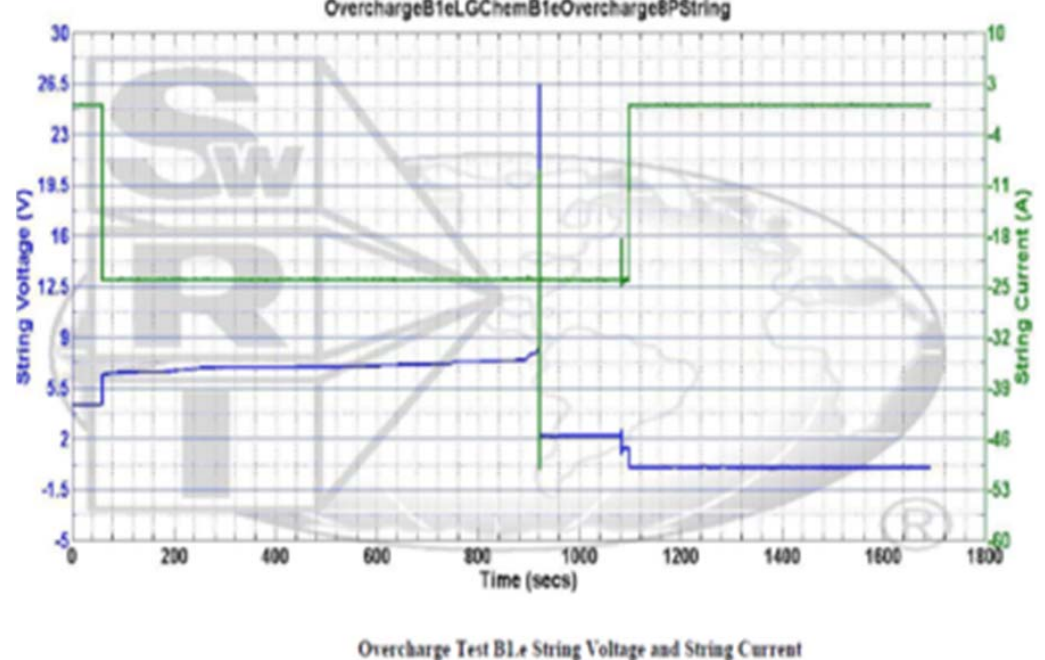

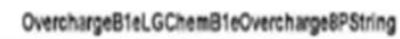

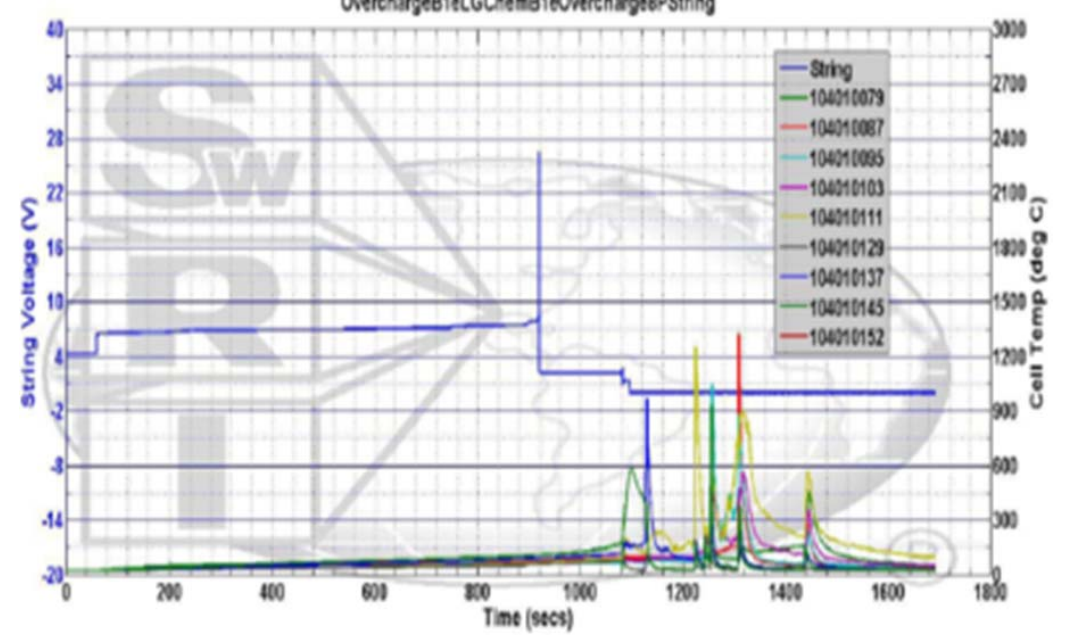

Orencharge Iest Bl \& String Voltage and Cell Temperature 


\section{Cell-Level External Short Circuit Test}

\section{Load $\leq 10 \mathrm{~m} \Omega$ for 2 hours}
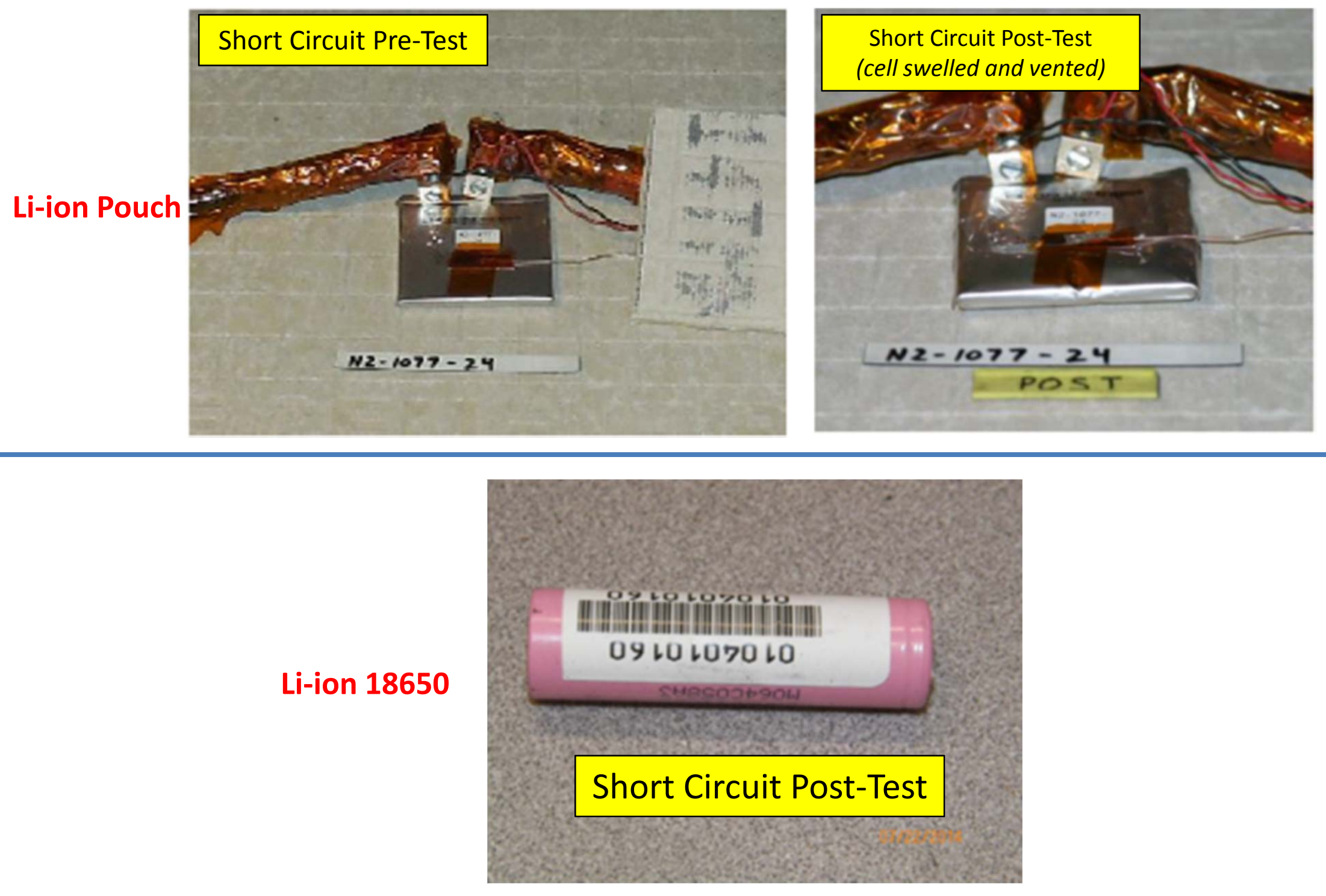


\section{Cell Level External Short Circuit Test}

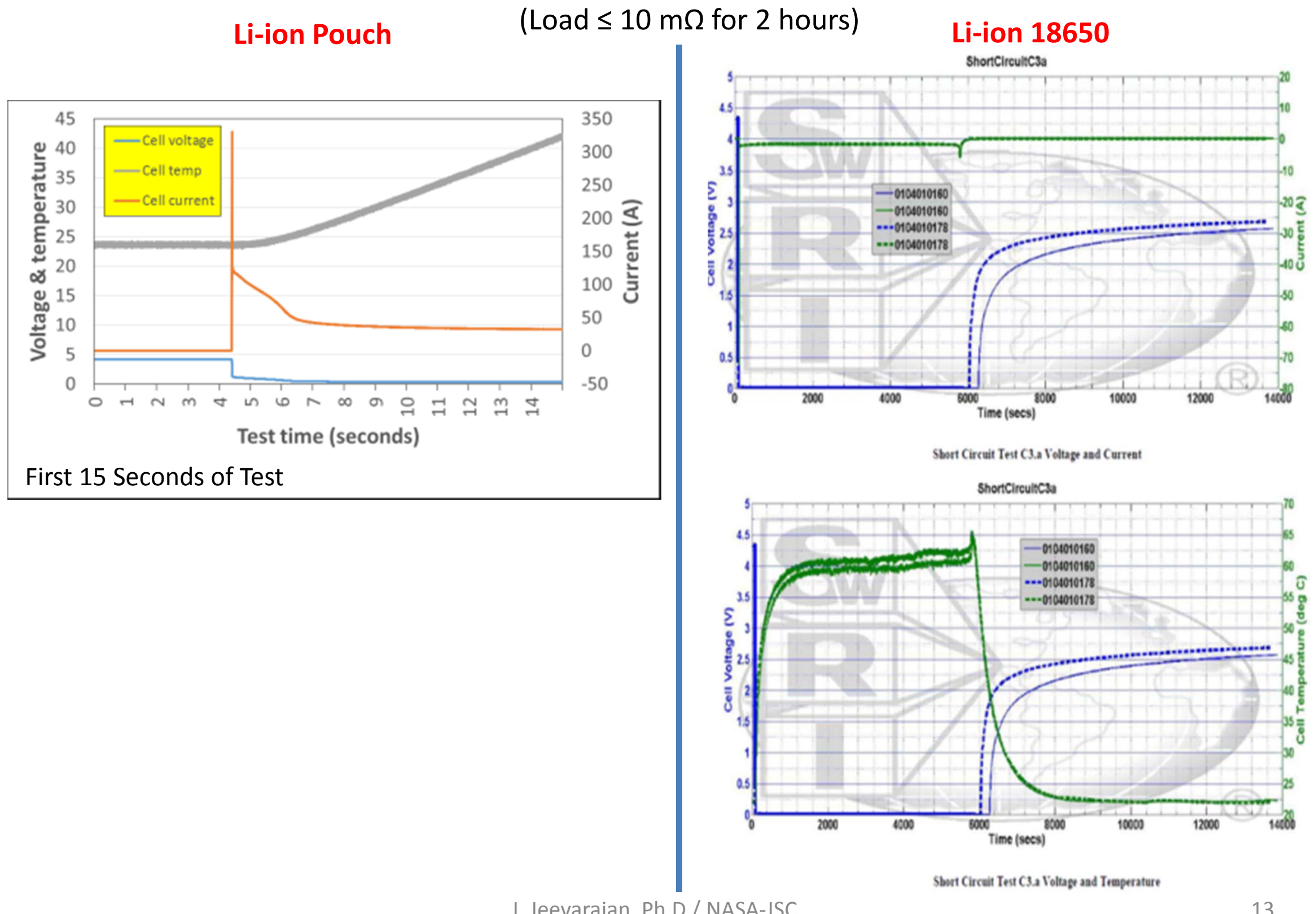




\section{S External Short Circuit Test at 100\% SOC}
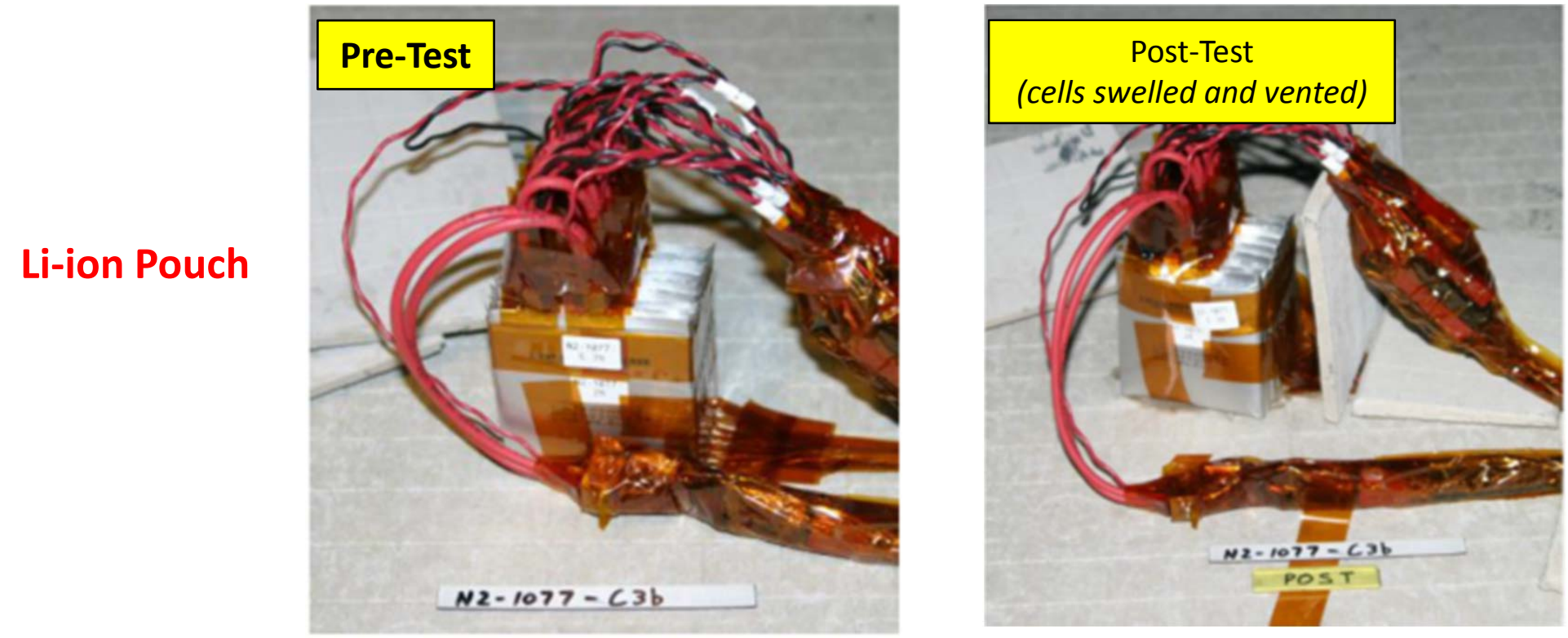

\section{Li-ion 18650}
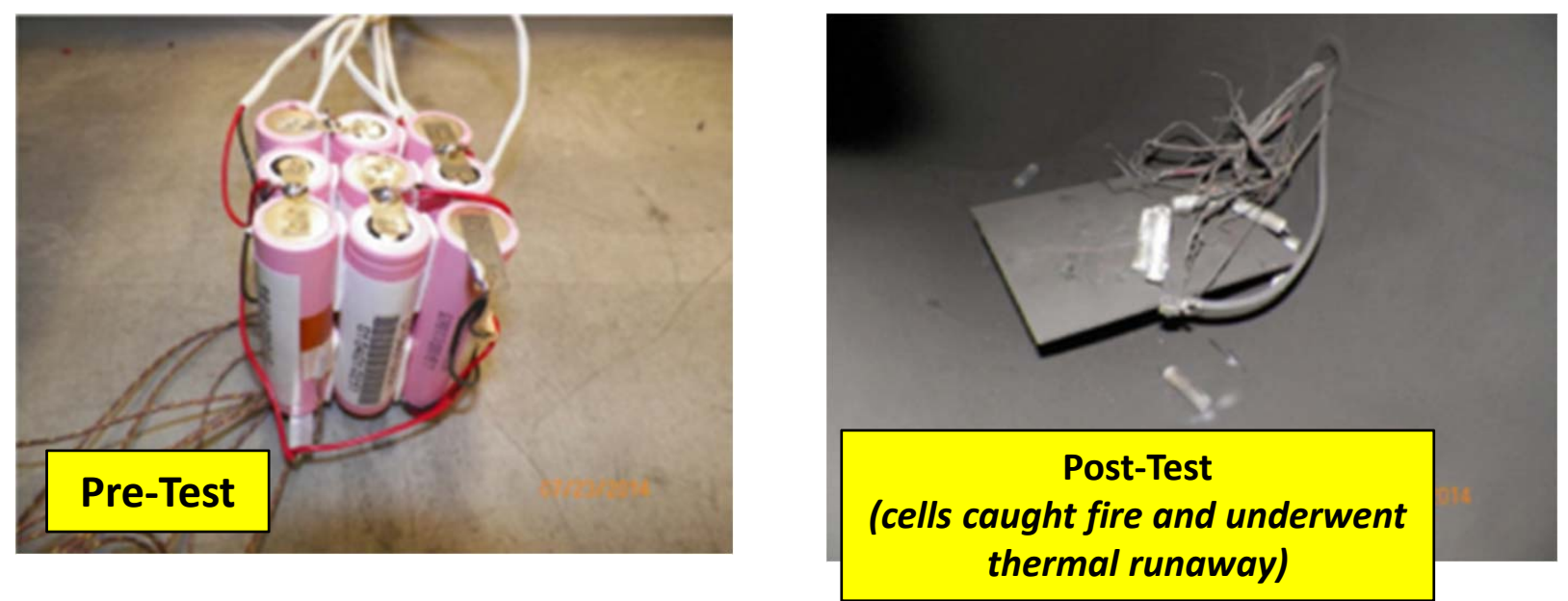

Cell Numbering for string is as follows.

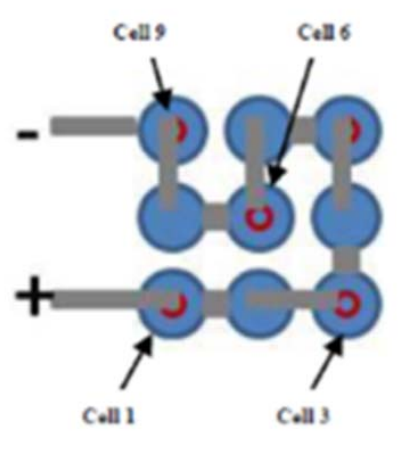




\section{S External Short Circuit Test at 100\% SOC}

Li-ion Pouch

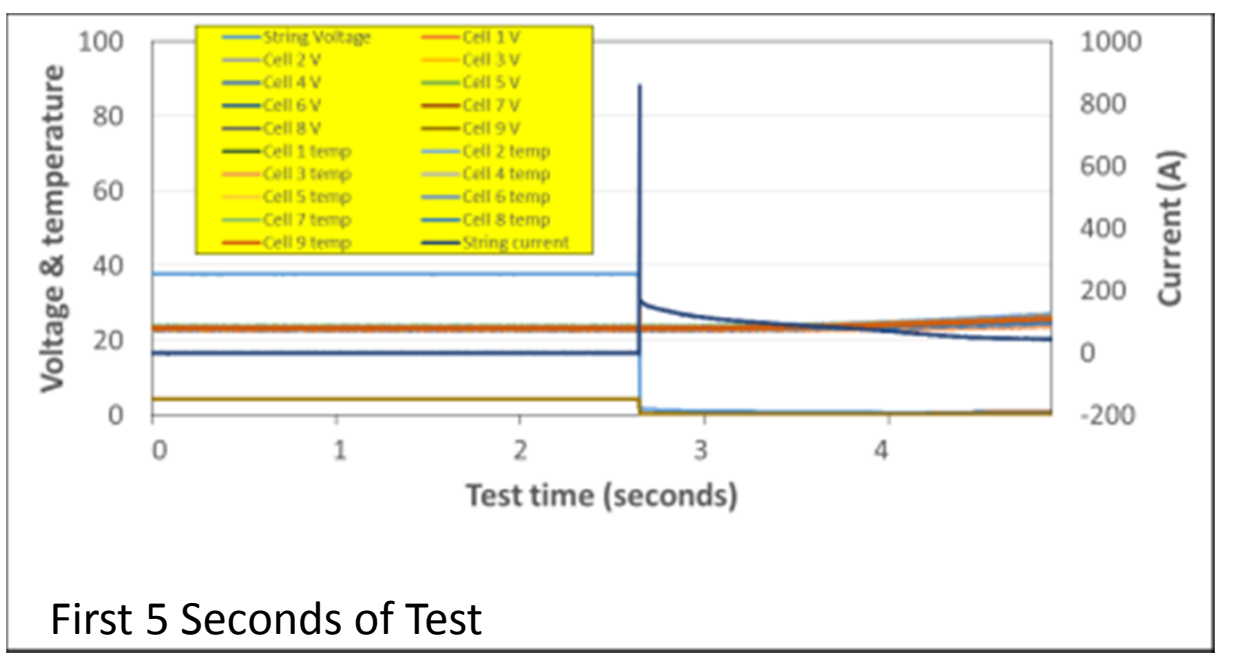

Li-ion 18650

ShontCireultcsb

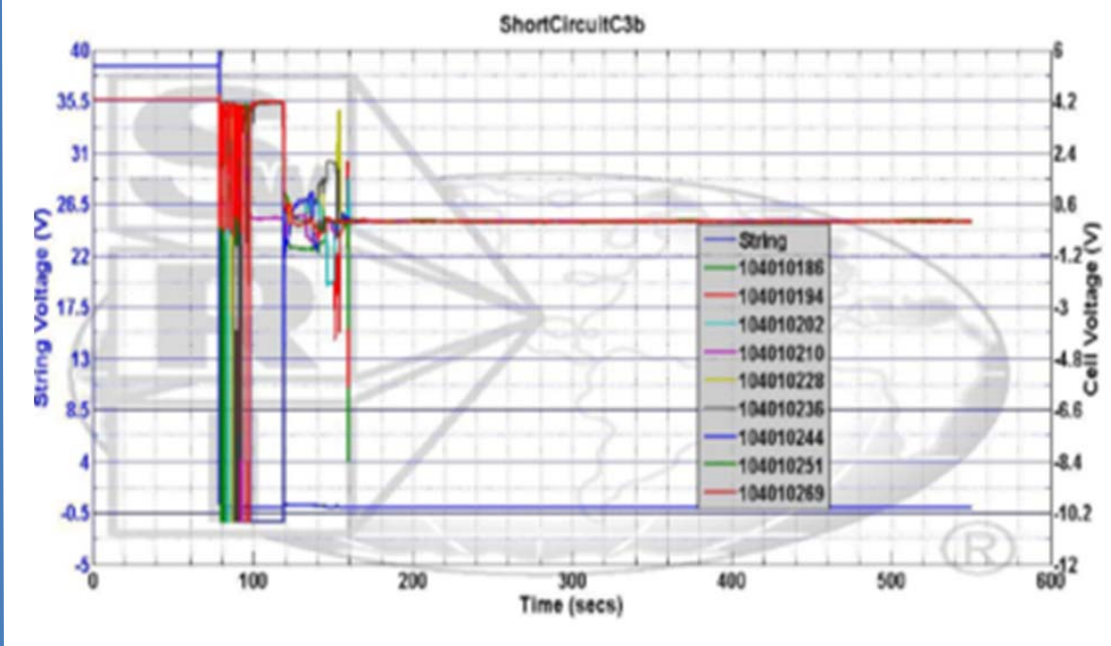

Shert Circuit Test CS Strine Voltate ad Coll Voltaten

Shoncireunc30

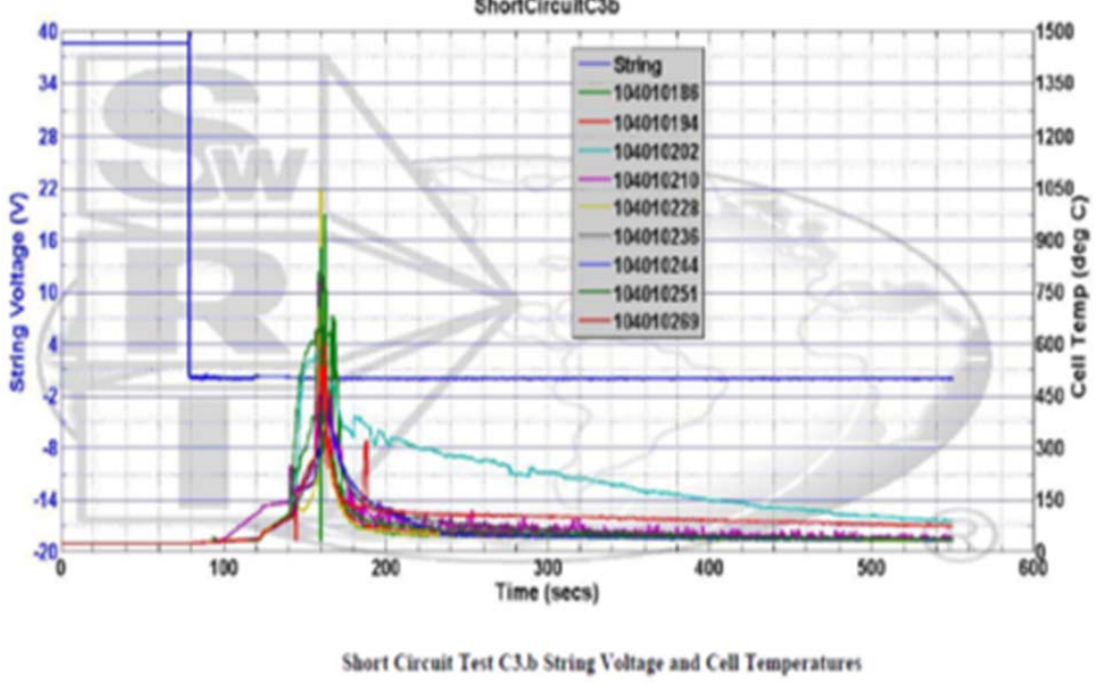

Stort Circuit Test CSB Striag Veltage and Cell Temperatures 


\section{S String External Short Circuit Test at 80\% SOC}

Both Modules were fully charged And then discharged by $20 \%$ ( $80 \%$ SOC or $20 \%$ DoD)
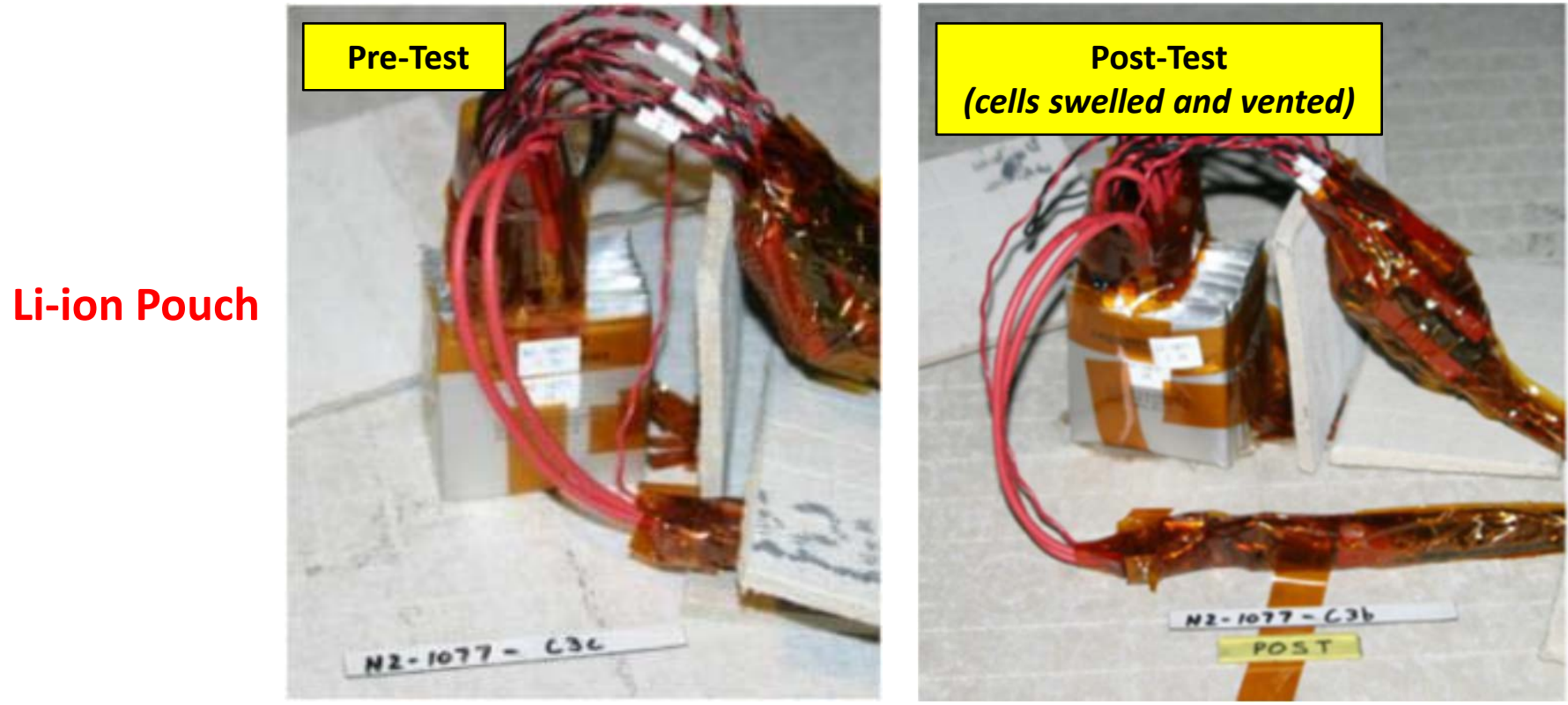

Li-ion 18650
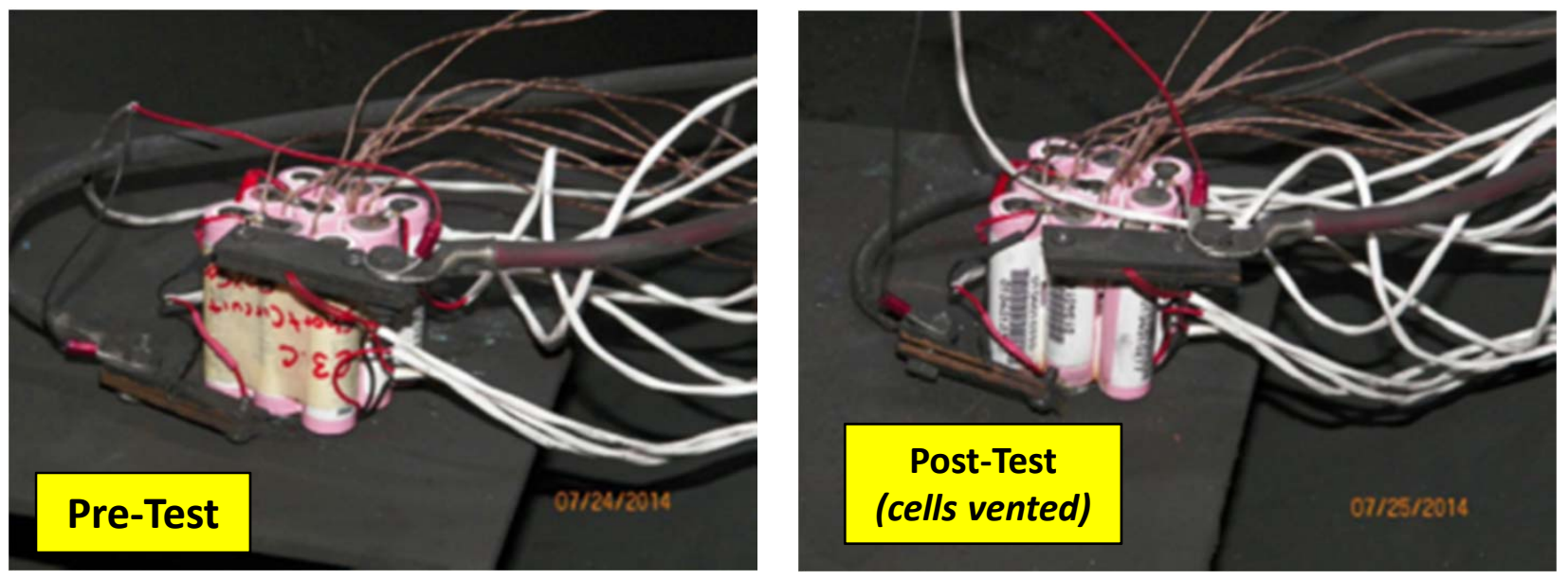

J. Jeevarajan, Ph.D./ NASA-JSC 


\section{S External Short Circuit Test at $80 \%$ SOC}
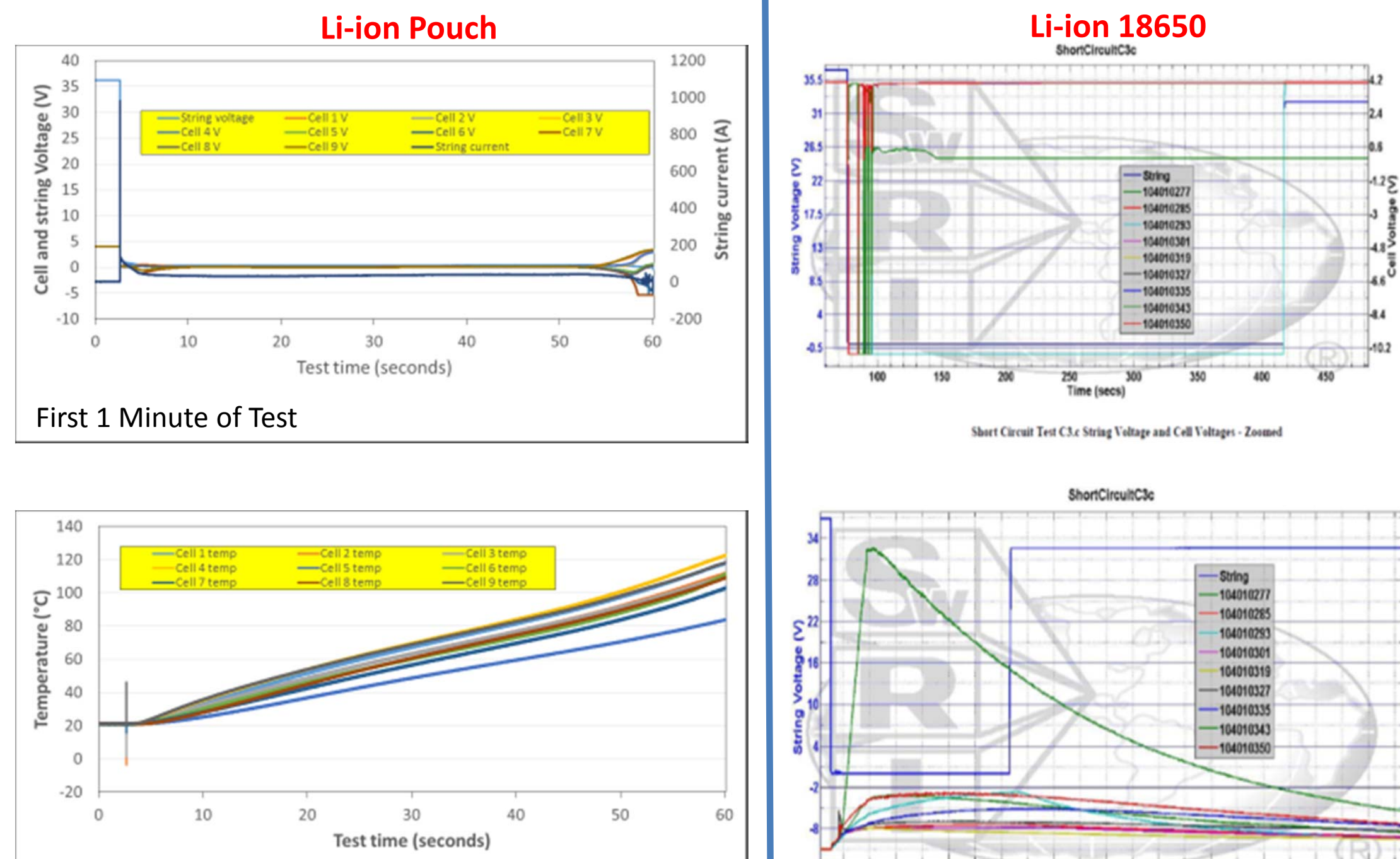

First 1 Minute of Test

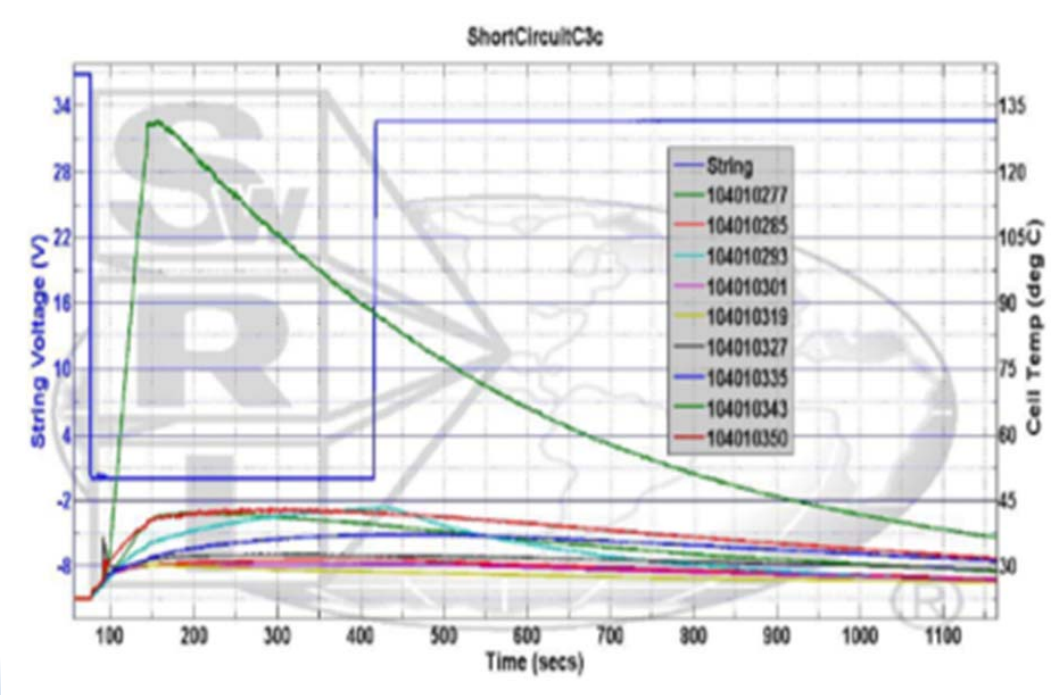

Stort Circuil Teat C3.c Striag Voltage and Cell Temperatures - Zcomed 


\section{S External Short Circuit Test at 70\% SOC}

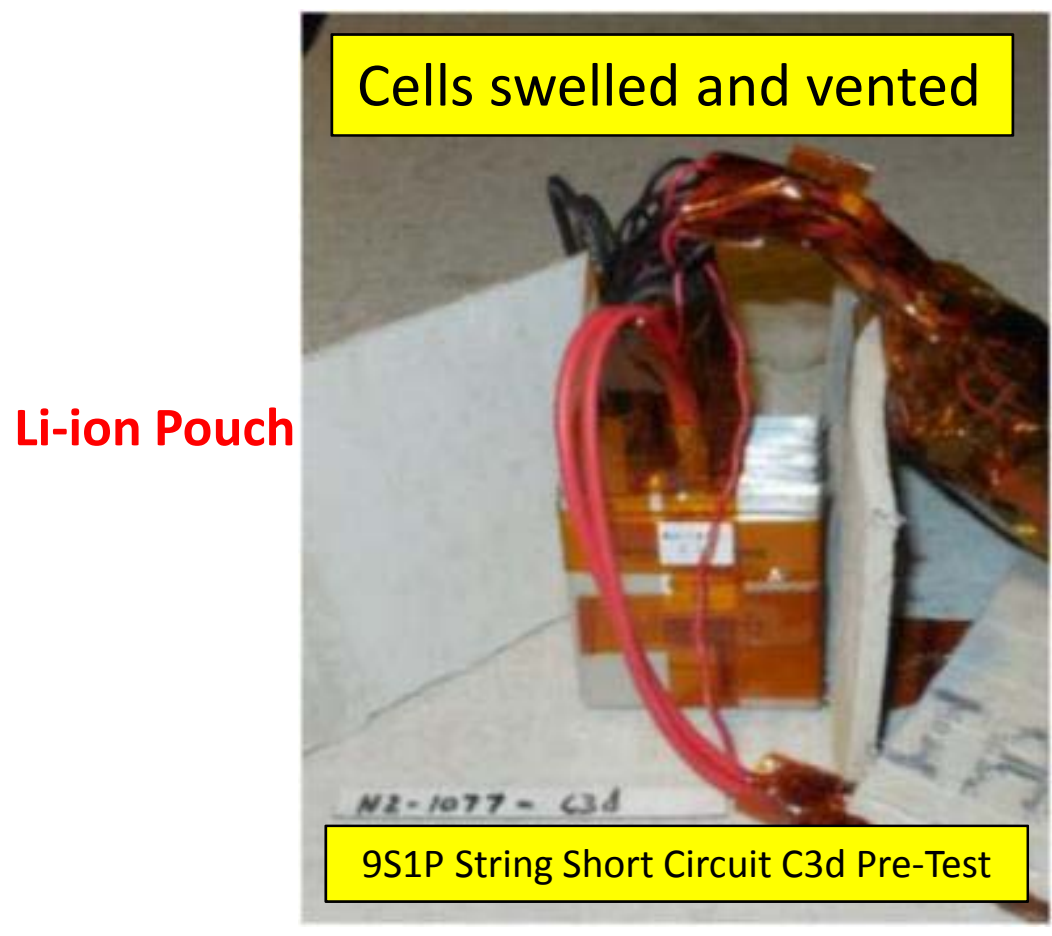

Li-ion 18650
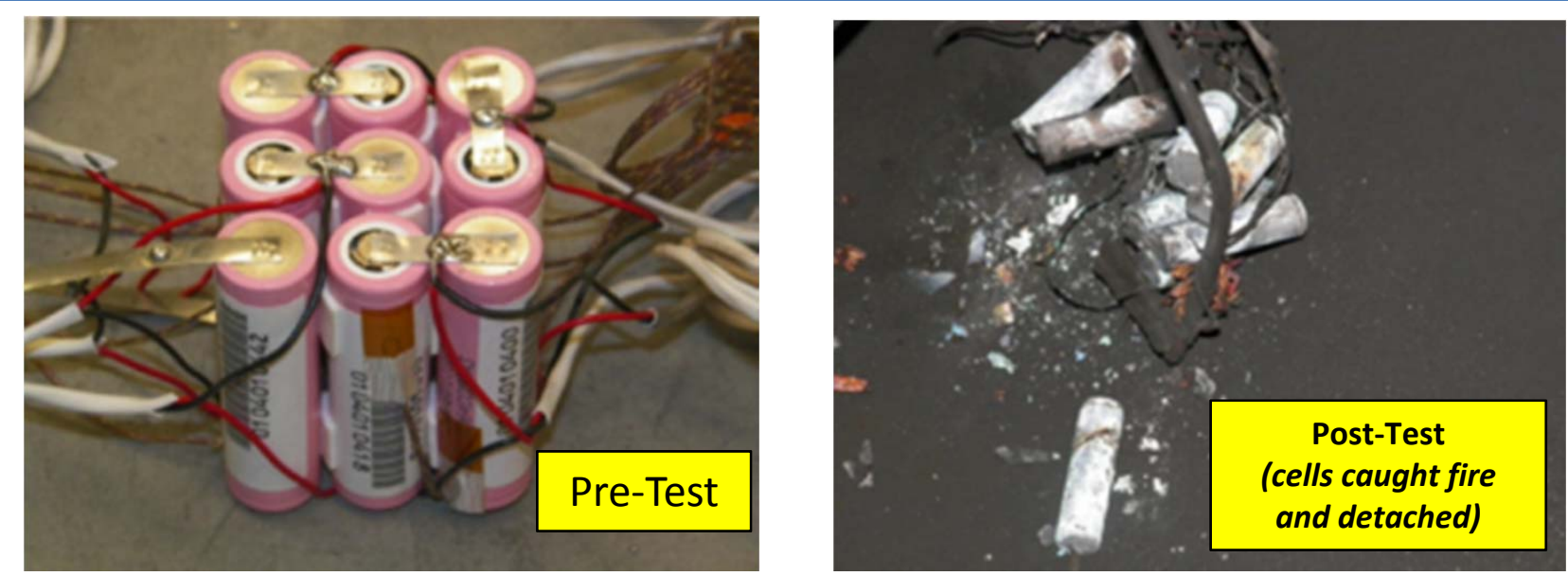


\section{S External Short Circuit Test at 70\% SOC}
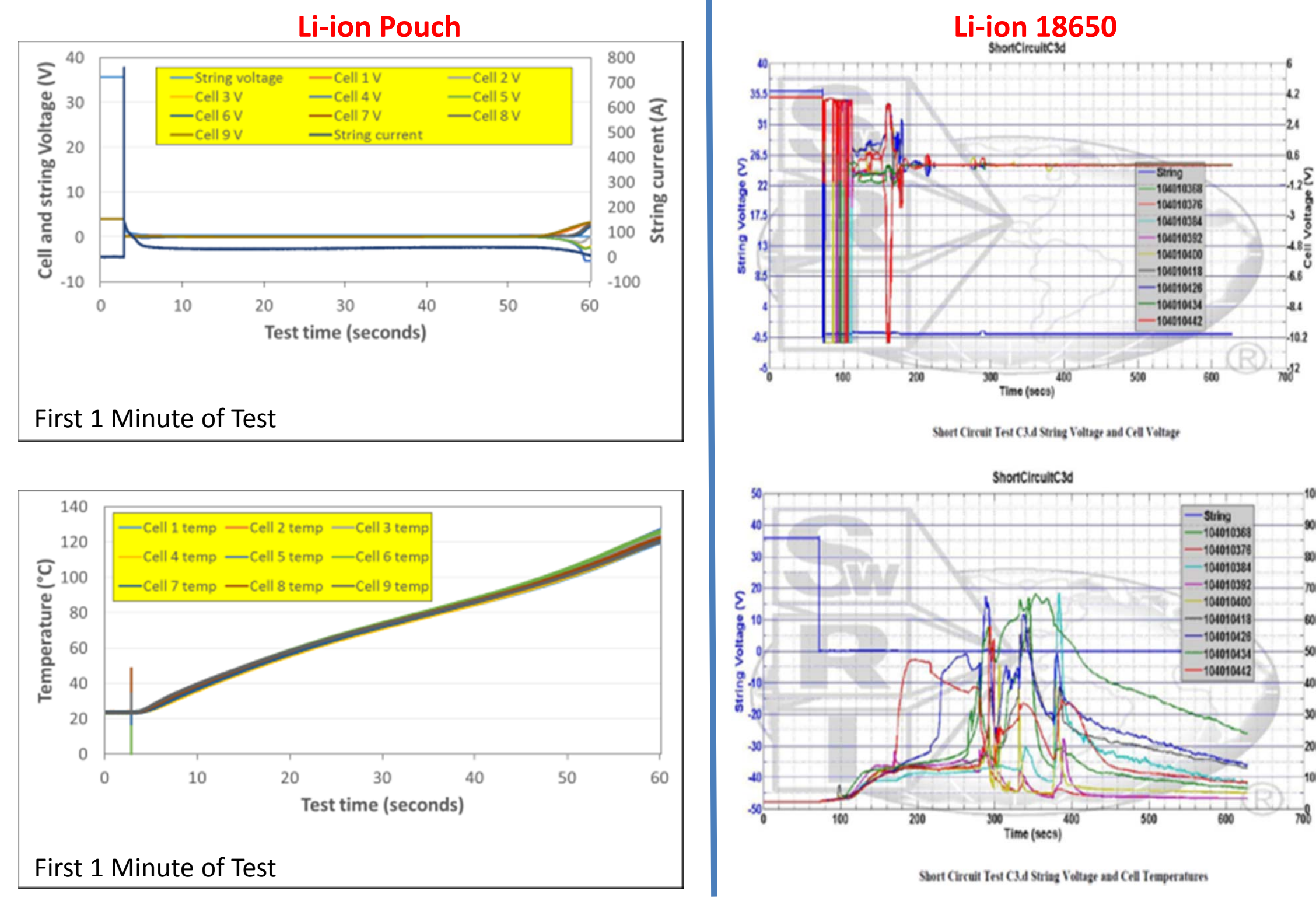

Shent Cirrait Tet CAd Strien Voltuge and Cell Voltoget

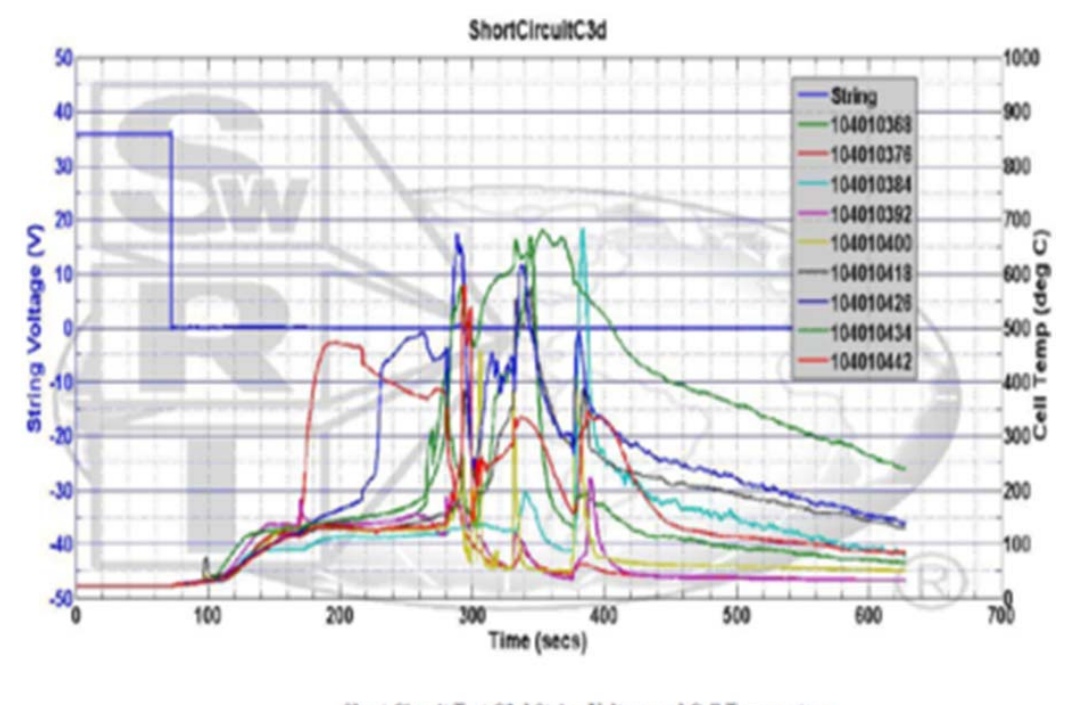

Stort Circuit Iest C.d Striaz Voltugr and Cell Iemperature 


\section{S External Short Circuit Test at 50\% SOC}
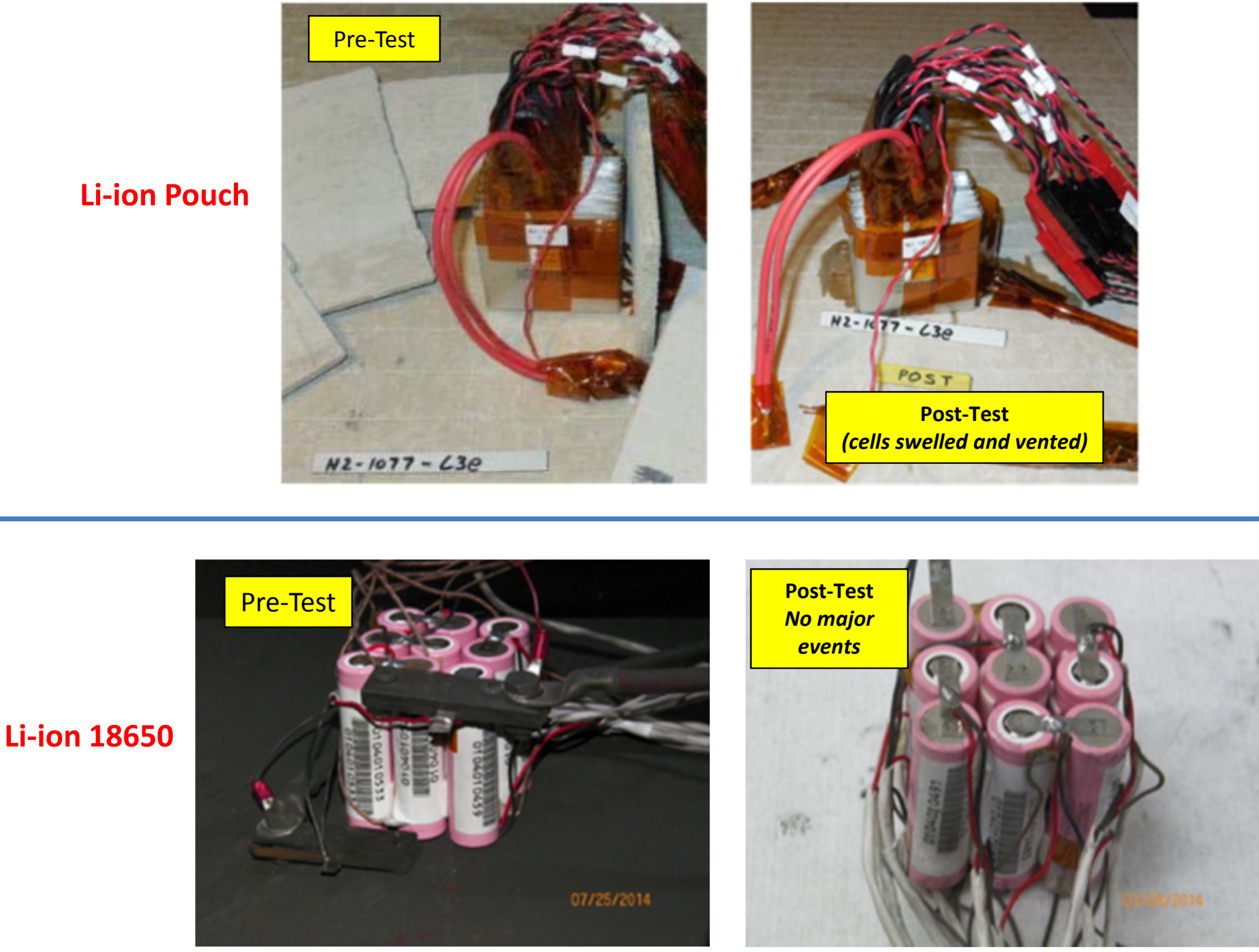

J. Jeevarajan, Ph.D./ NASA-JSC 


\section{S External Short Circuit Test at 50\% SOC}

Li-ion Pouch
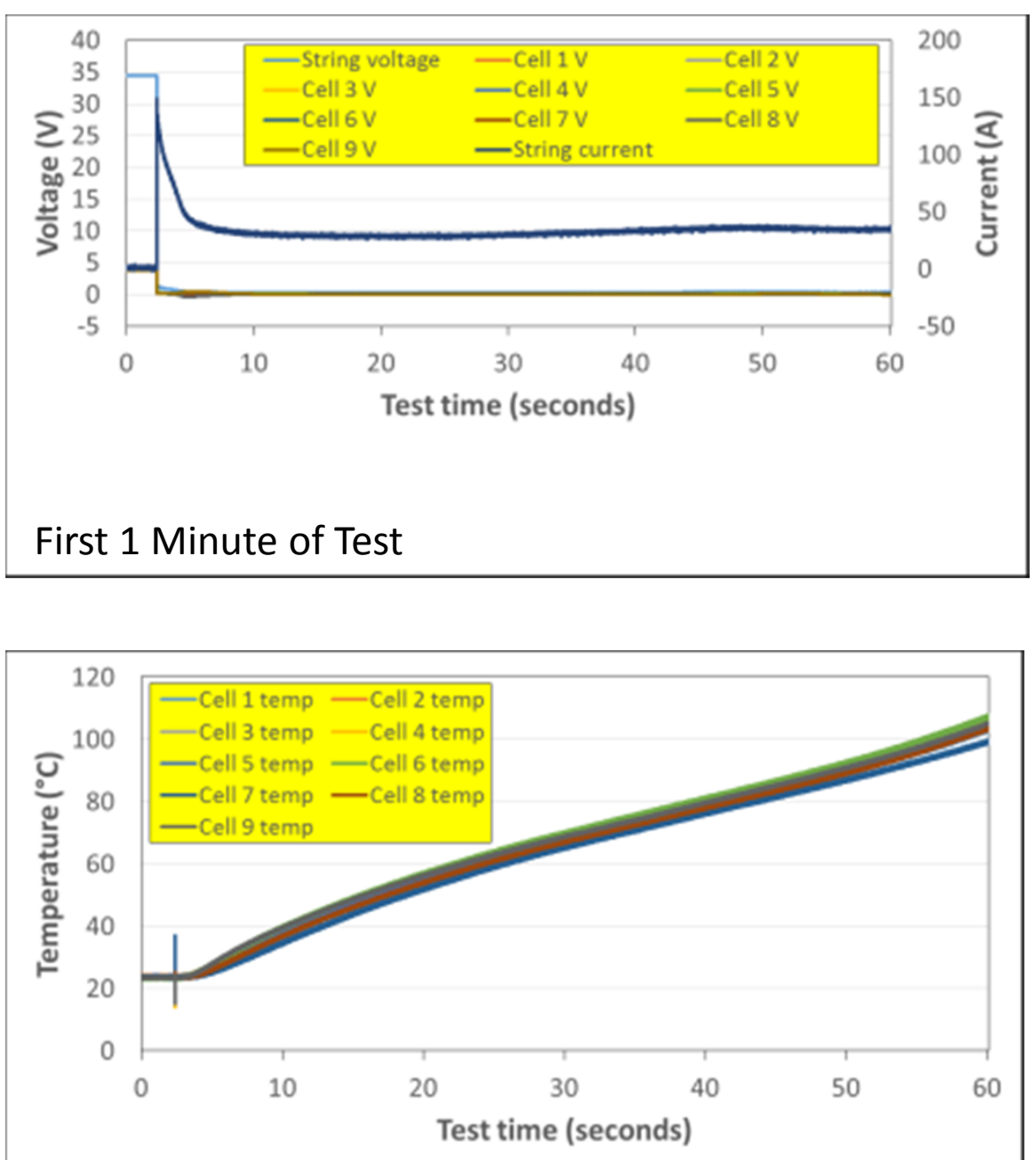

First 1 Minute of Test
Li-ion 18650

shoncireulitcse

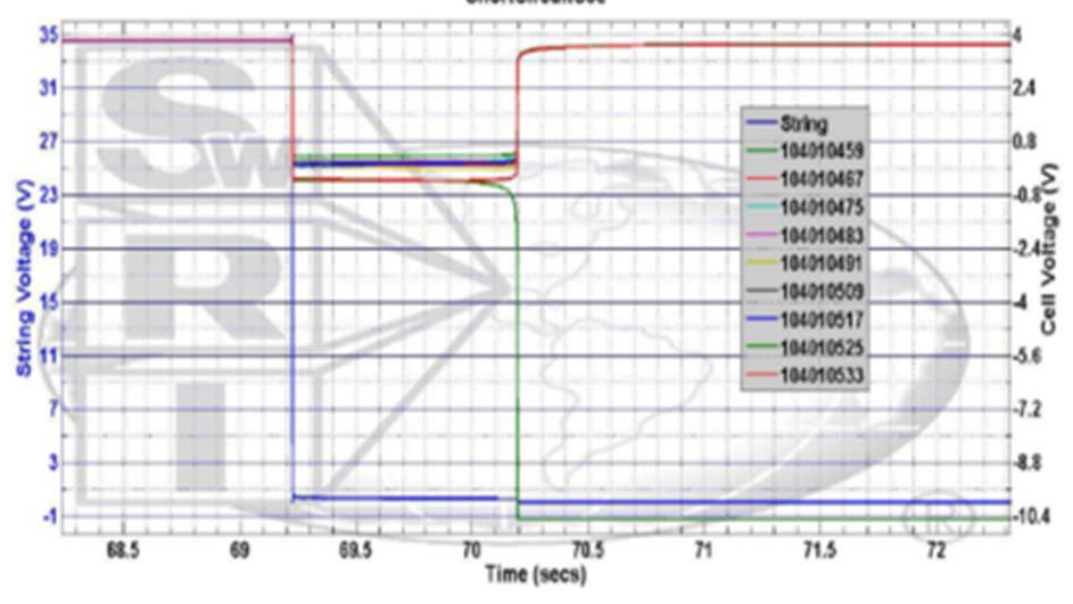

Stort Circuit Iest C3e String Voltage and Cell Voltagen - Zoomed

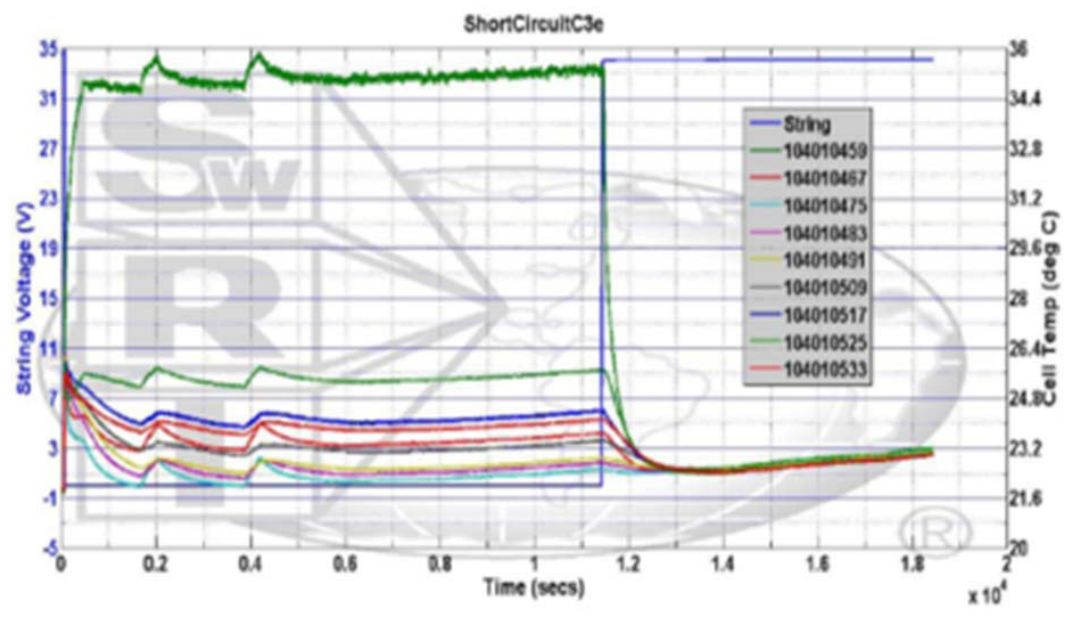

Stort Circuit Tet Cre String Voltage and Cell Temperateres 


\section{P Bank External Short Circuit Test at $\mathbf{1 0 0 \%}$ SOC}
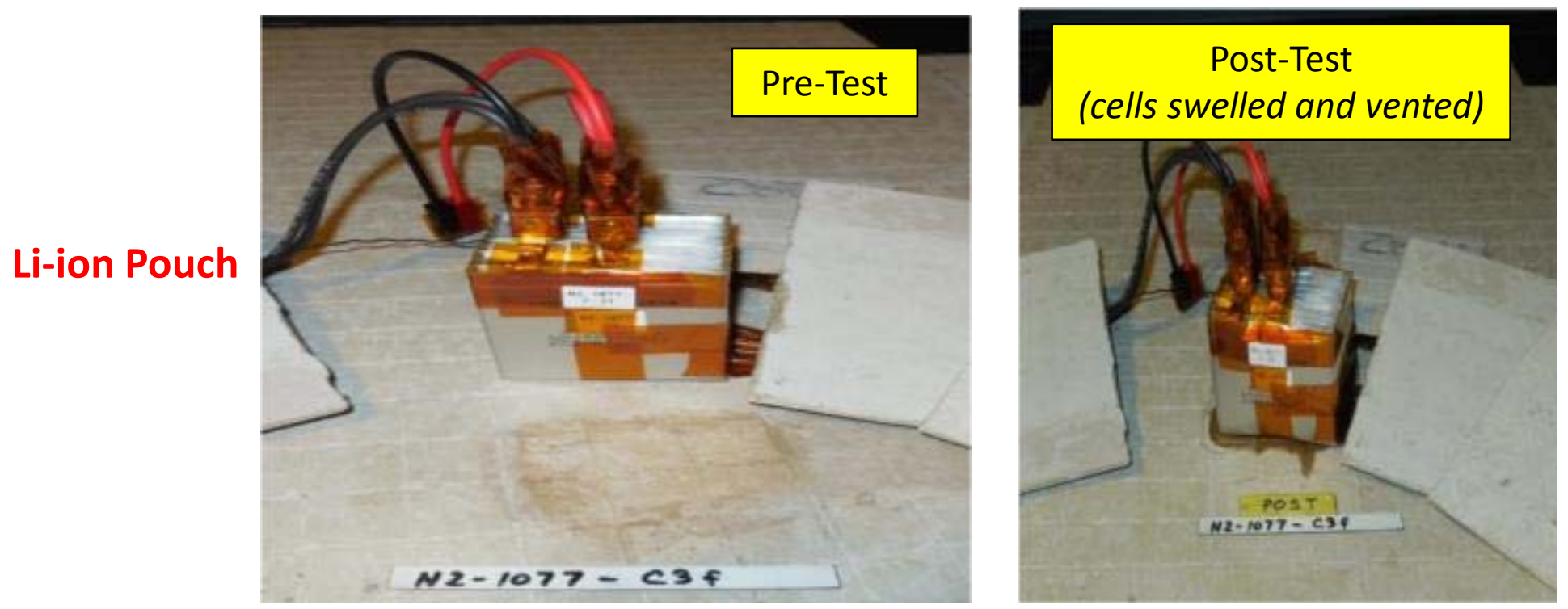

8P Bank External Short Circuit Test at 100\% SOC

Li-ion 18650
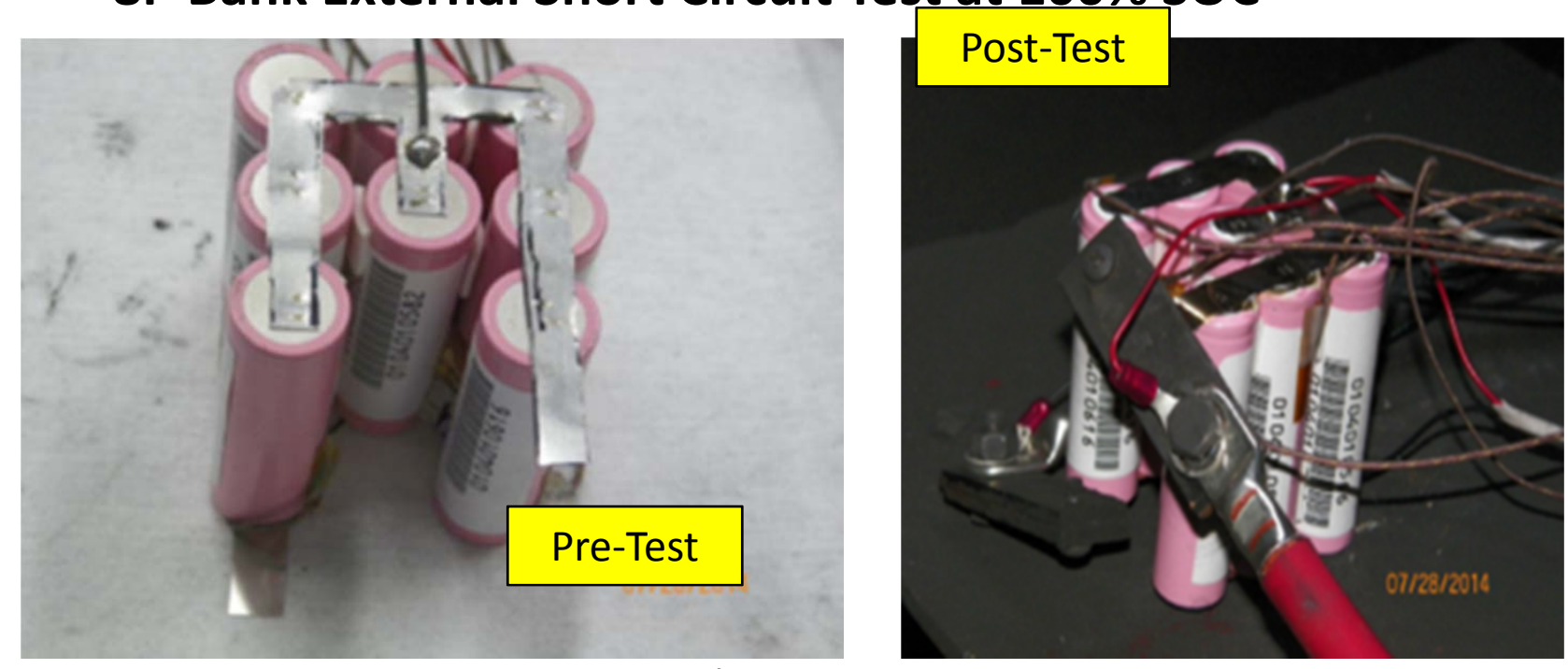


\section{Bank External Short Circuit Test at 100\% SOC}
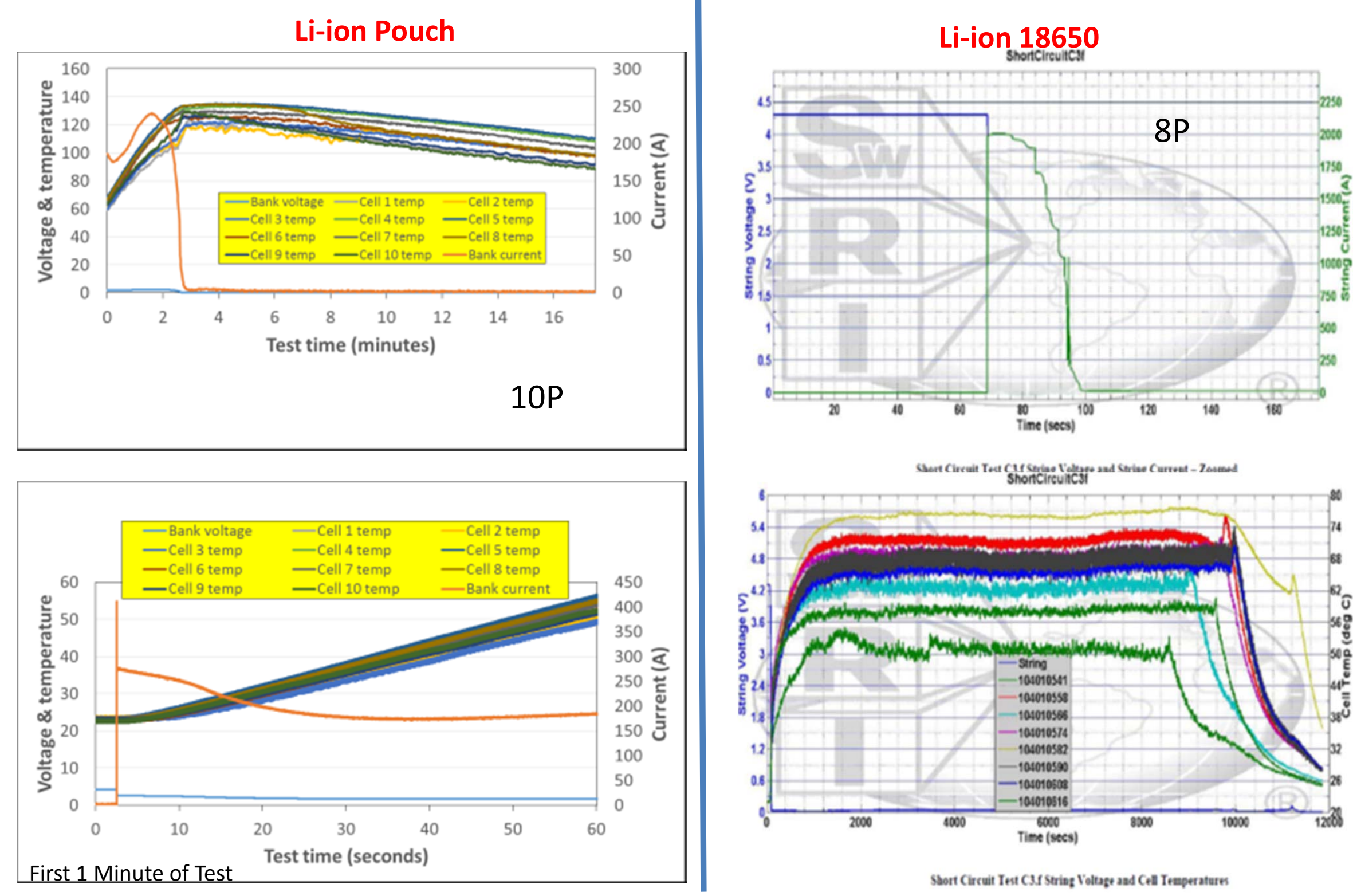

Stort Circuit Iest C3r String Voltage aad Cell Iemperatures 


\section{Li-ion 18650 Cell Vent Pressure Test}

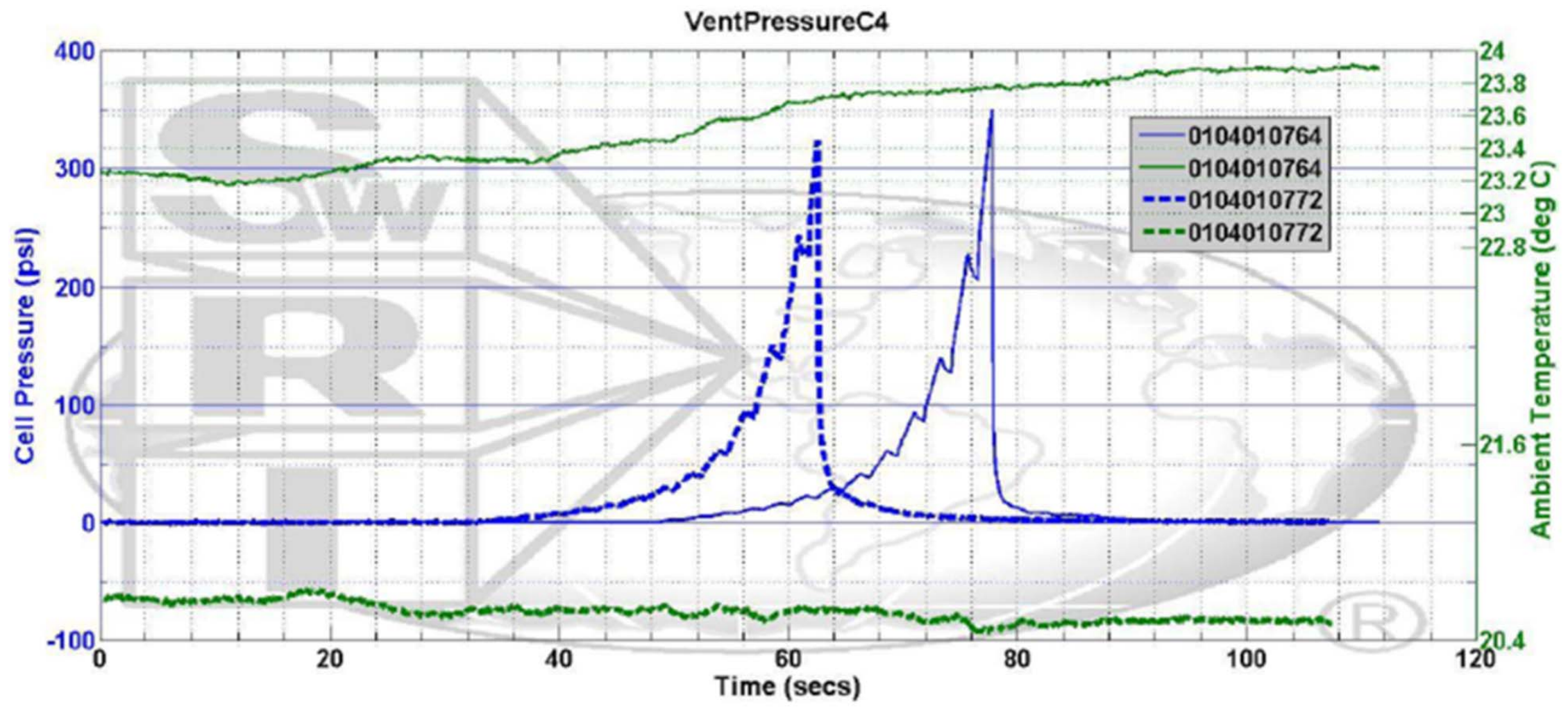

Vent Pressure Test Pressure and Ambient Temperature 


\section{Li-ion Pouch Cell Burst Pressure Test}

\section{4 Burst pressure test $(2$ cells)}

A small hole was pierced in the center of a fully discharged cell. A valve was affixed over the hole using a suitable adhesive. The cell was placed in a fixture and suspended in mineral oil. A tank of argon gas was connected to the valve. The pressure was slowly increased until the cell jacket burst, as evidenced by bubbles in the oil.
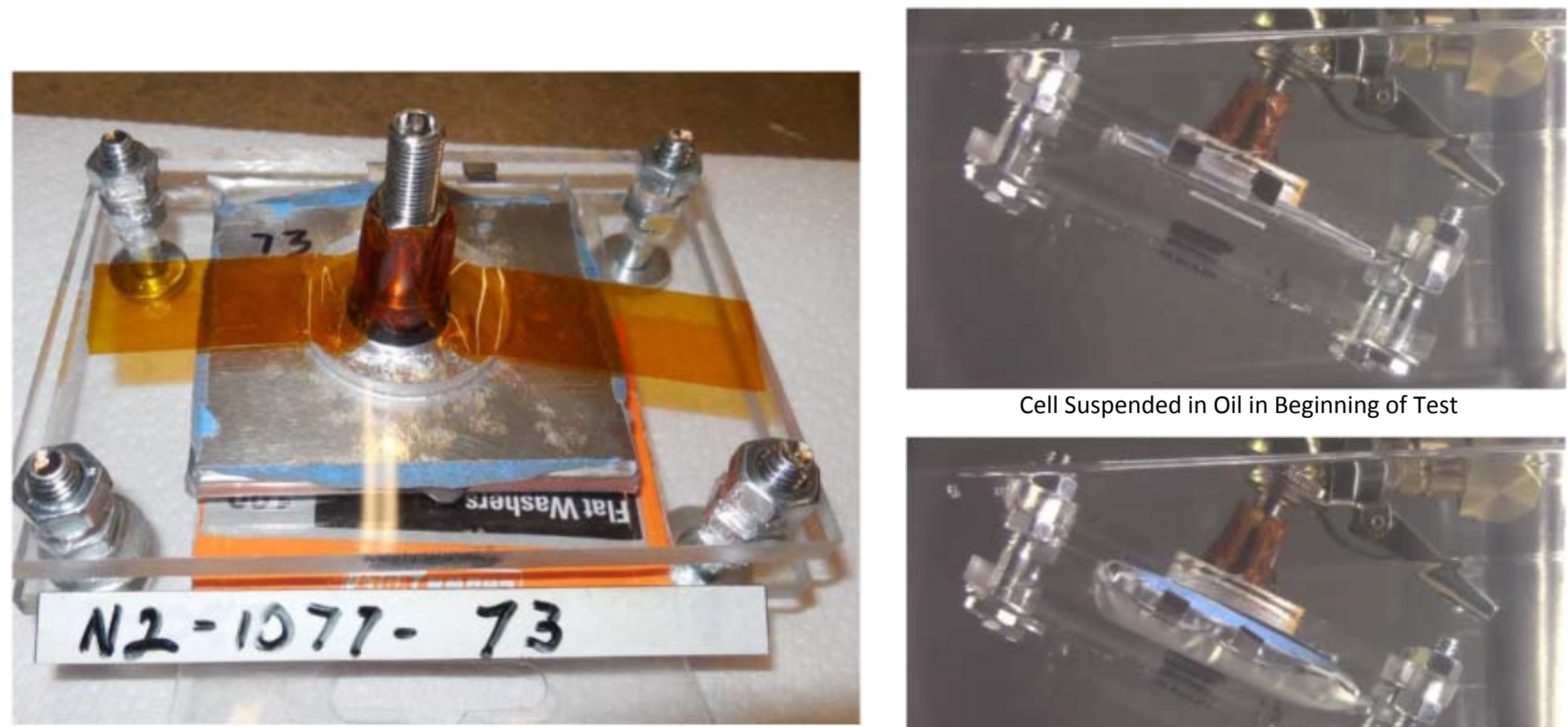

Cell Suspended in Oil in Beginning of Test

Cell Burst Pressure Test Set-Up

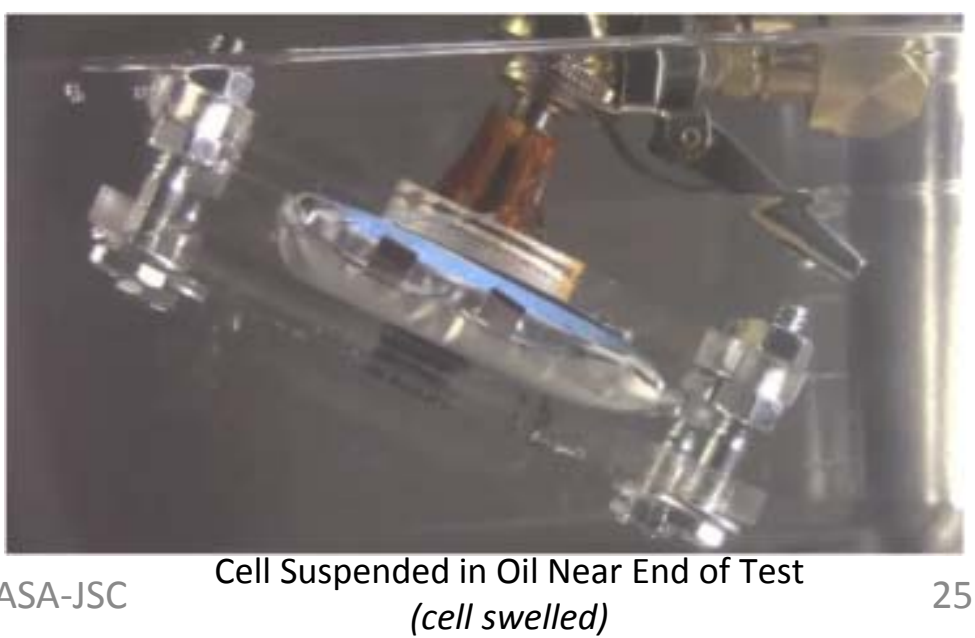




\section{Li-ion Pouch Cell Burst Pressure Test Results}

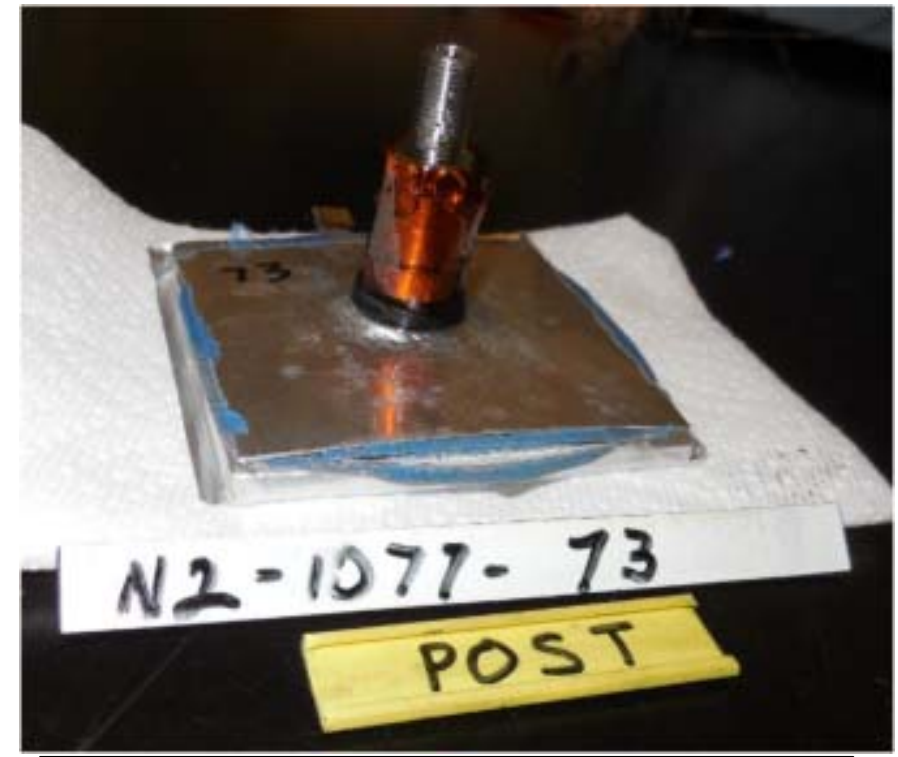

Cell burst at 18.55 psi. The cell bust along the edge opposite the tabs.

(Note: This is a folded edge, not a sealed seam.)

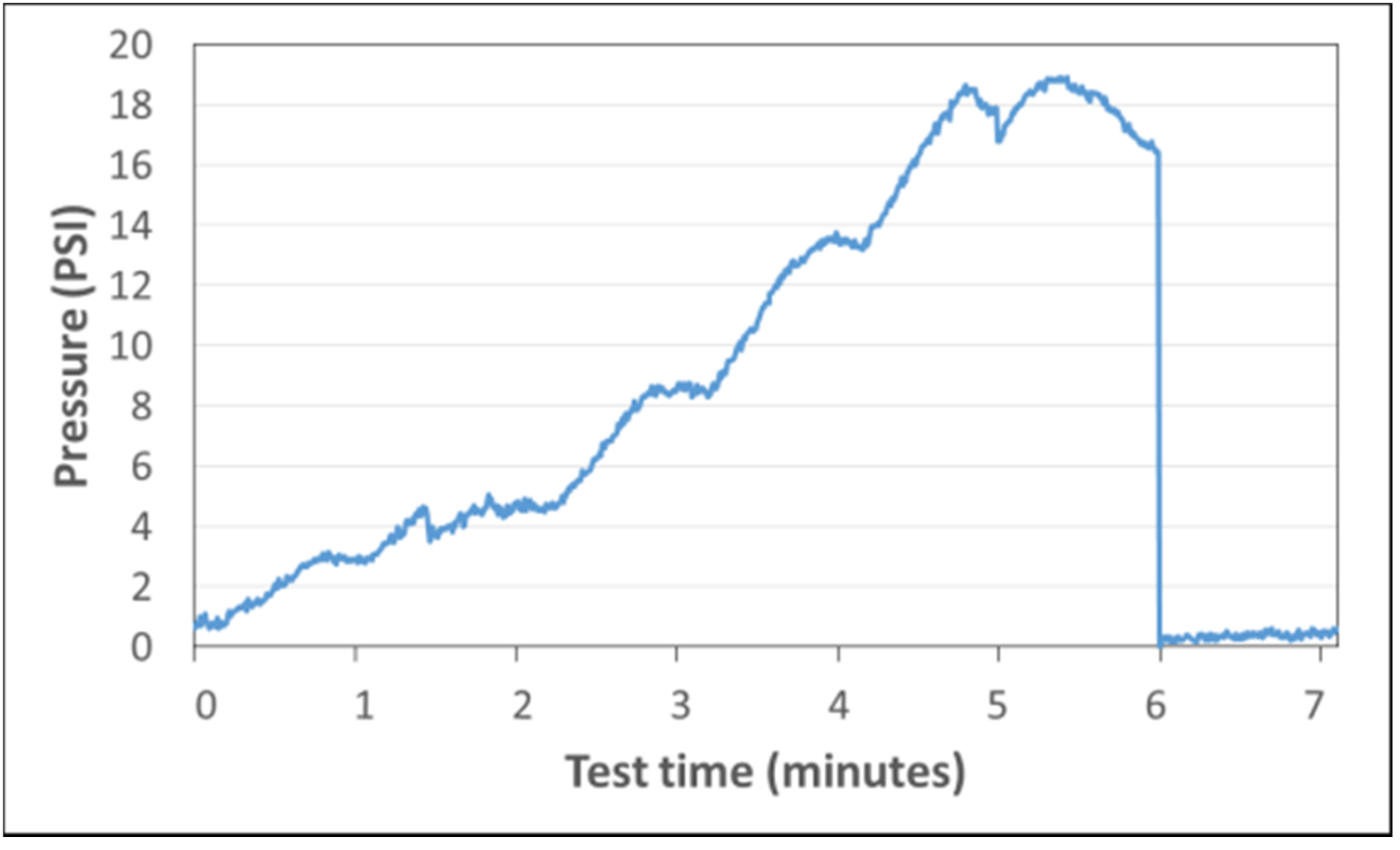




\section{Li-ion Pouch Cell Heat-to-Vent Test at $100 \%$ SOC}
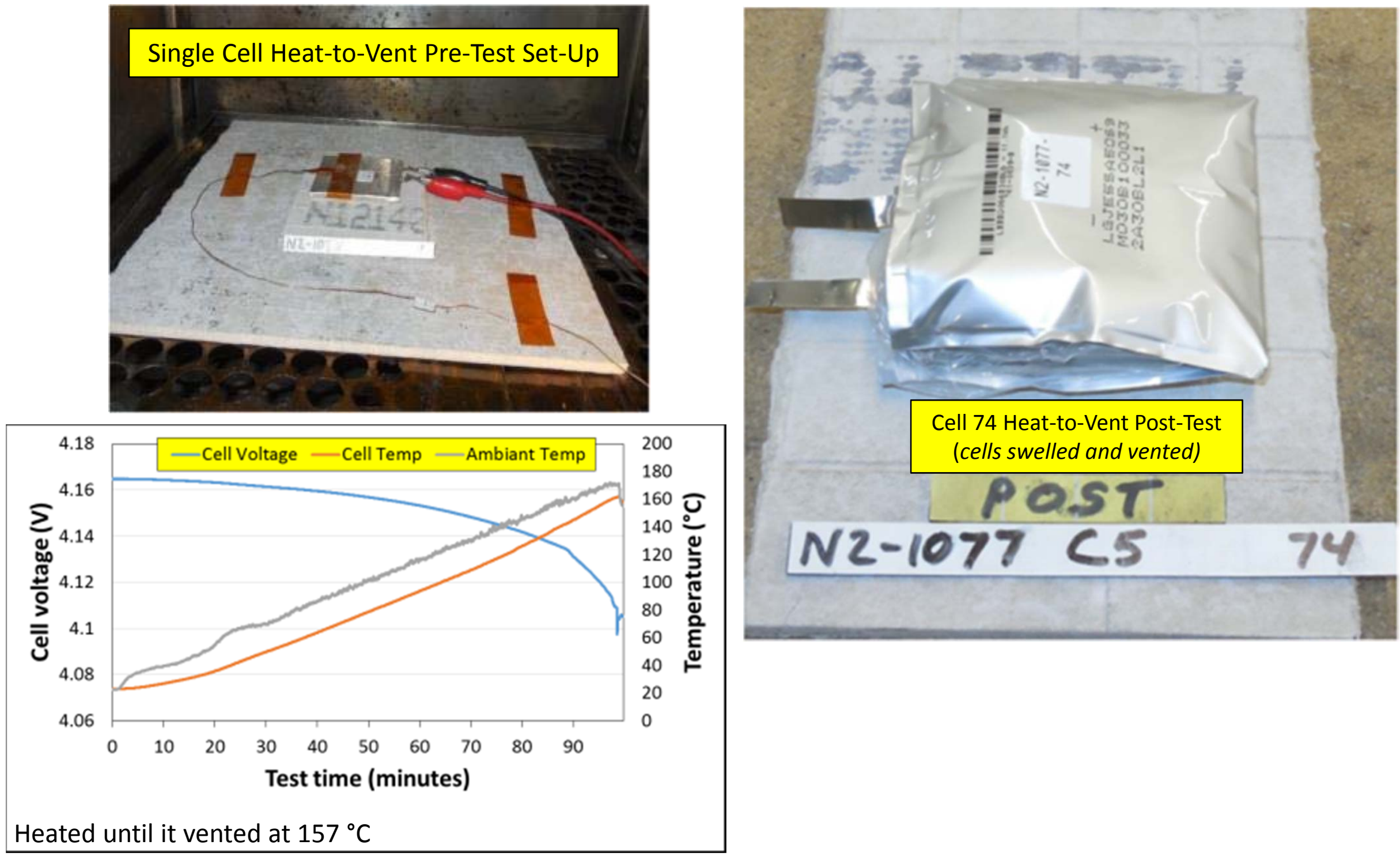


\section{Li-ion 18650 Cell Heat-to-Vent Test at 100\% SOC}
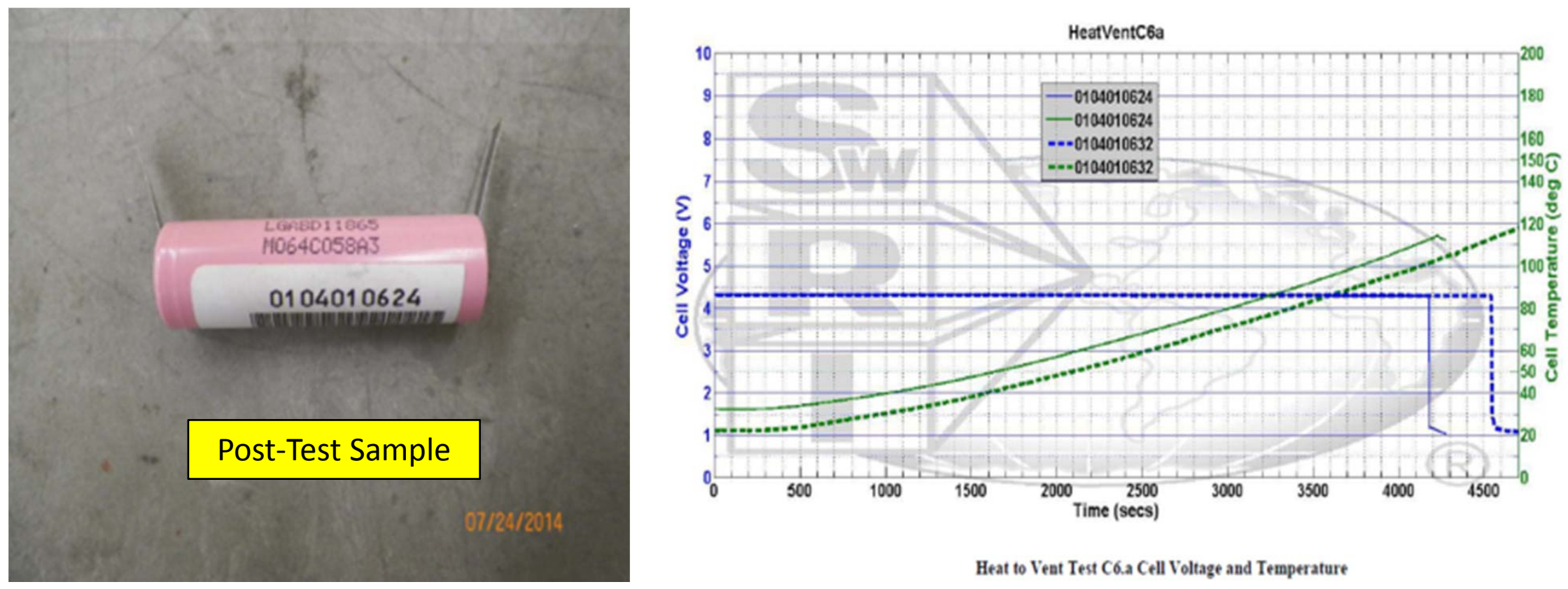

Heat damage observed at positive end 


\section{Li-ion Pouch Cell Heat-to-Vent Test (70\% SOC)}

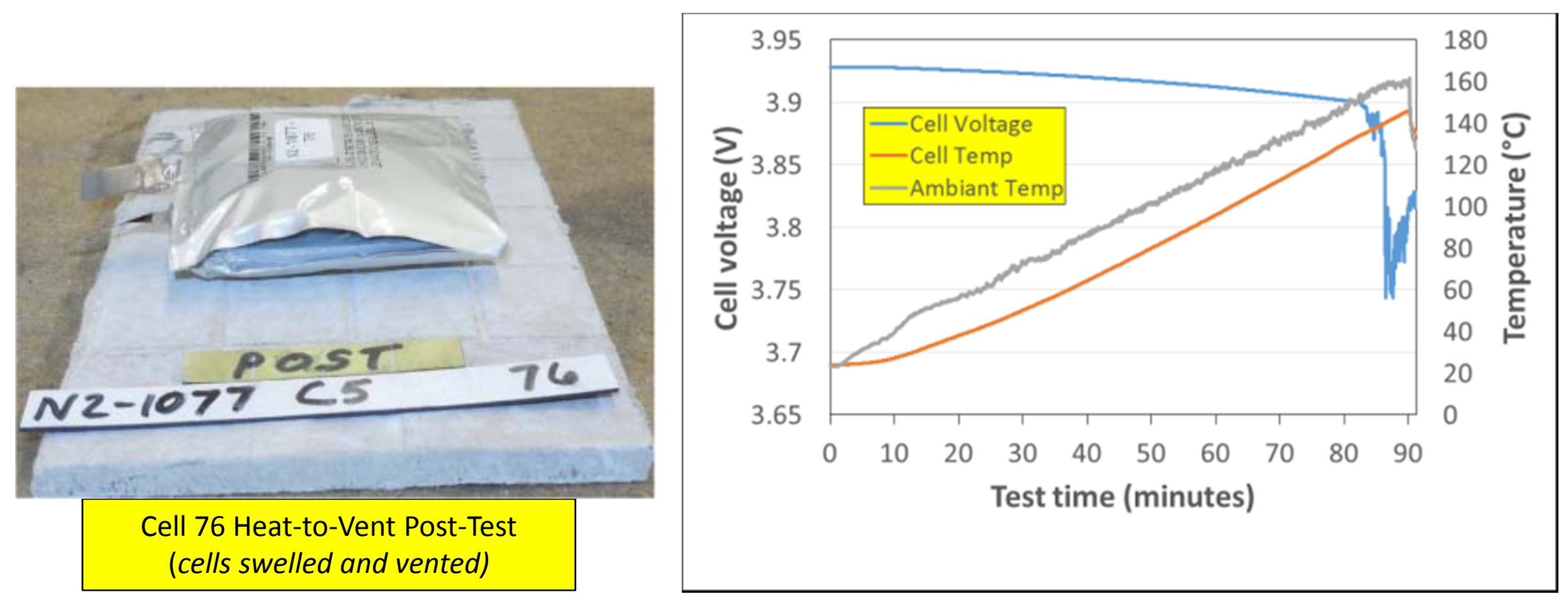




\section{Li-ion Pouch Cell Heat-to-Vent Test (50\% SOC)}

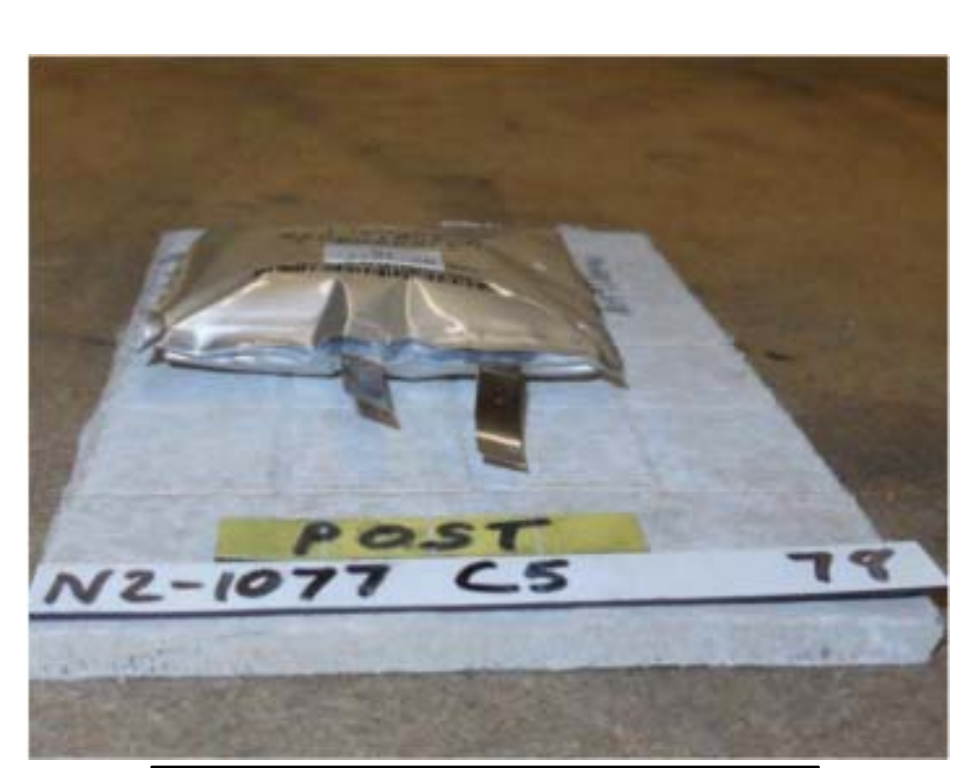

Cell 78 Heat-to-Vent Post-Test (cells swelled and vented)

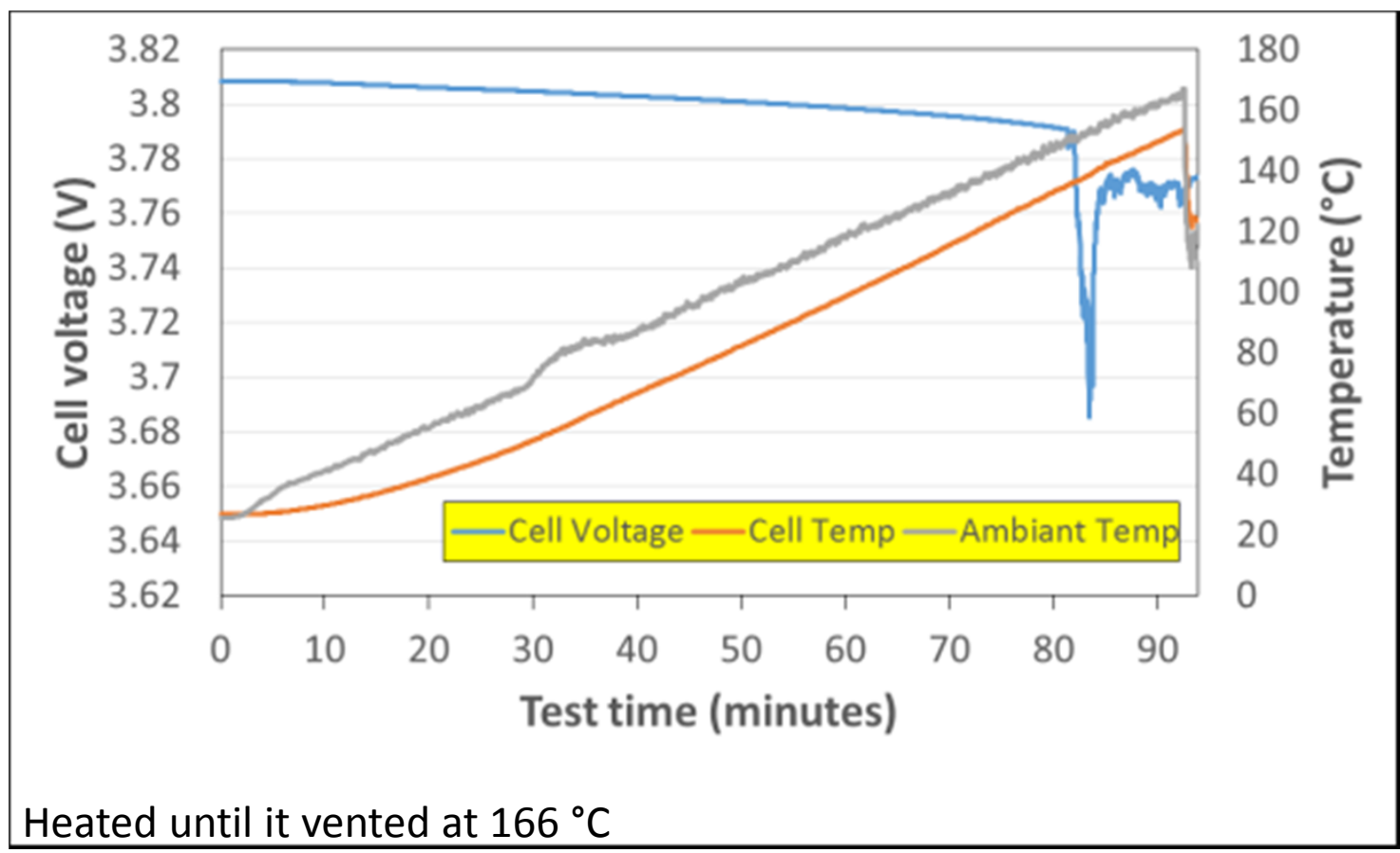




\section{Li-ion 18650 Heat-to-Vent Test at 70\% SOC}
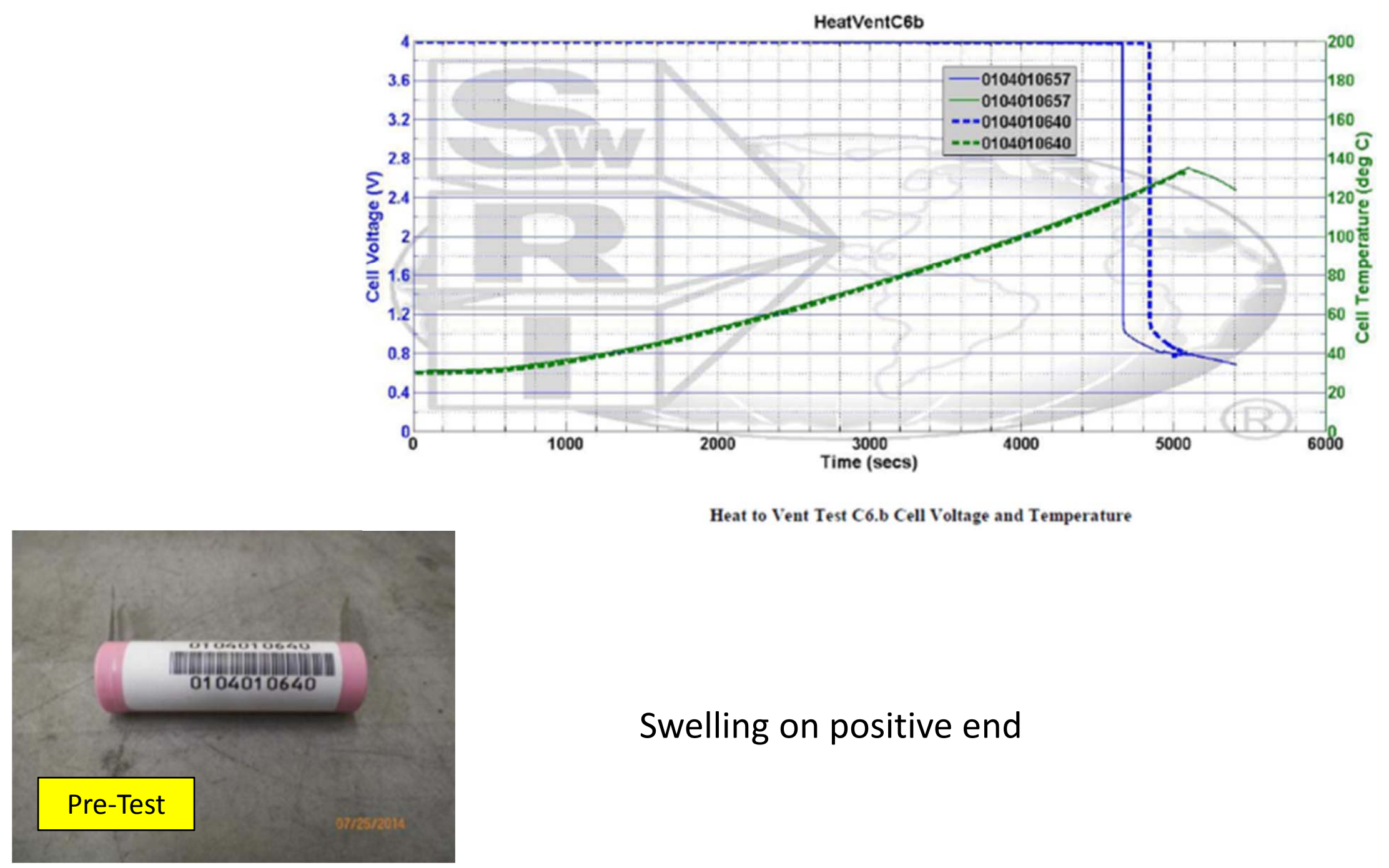

Swelling on positive end 


\section{Li-Ion 18650 Heat to vent at 50\% SOC}

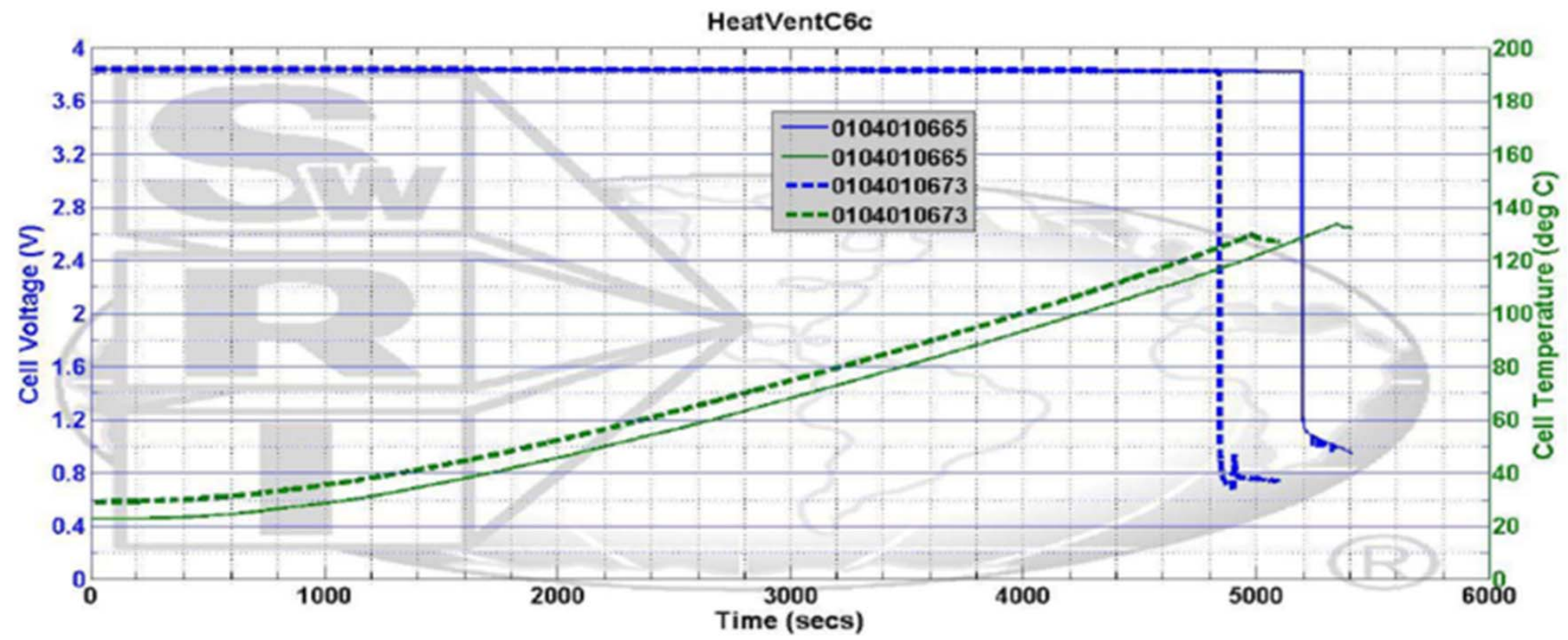

Heat to Vent Test C6.c Cell Voltage and Temperature

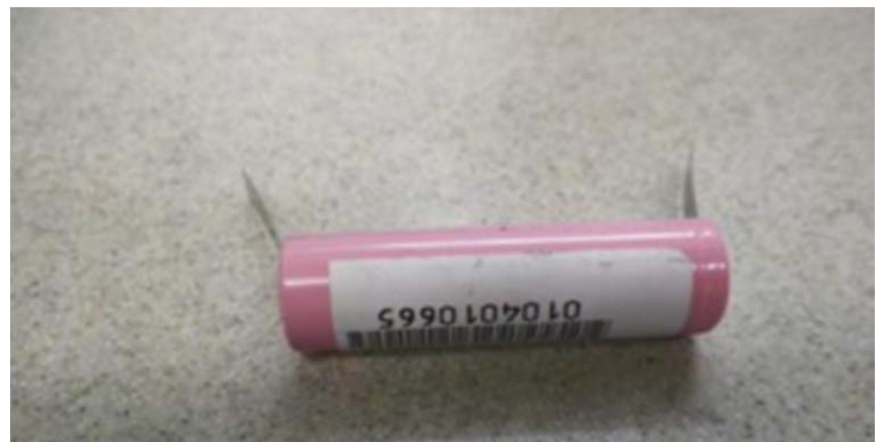

Post-Test

No apparent damage 


\section{Summary}

- The LG 18650 li-ion cells have a tolerance to off-nominal conditions at the single cell level.

- The LG polymer/pouch li-ion cells do not have the same tolerance to off-nominal conditions at the single cell level. The cells go into thermal runaway at $1 \mathrm{C}$ and $0.5 \mathrm{C}$ rates of overcharge current.

- Neither cell designs show a tolerance to overcharge at the bank level.

- The LG pouch cells do not show tolerance to an external short at the cell or string and bank level at various SOC. They swell and exhibit venting but do not go into thermal runaway.

- The LG 18650 li-ion cells in strings display venting or thermal runaway when subjected to external short tests at different SOC except the $50 \%$ SOC where very low temperatures were observed.

- The LG 18650 cells in a 8P bank configuration when subjected to an external short displayed no venting at full $\mathrm{SOC}$ with temperatures below $100^{\circ} \mathrm{C}$ through the entire test.

- The LG pouch cells under the heat to vent tests at different SOC, did not exhibit any thermal runaway but showed cell swelling under all SOC with venting occurring at almost the same temperatures irrespective of SOC.

- The LG 18650 cells, under the heat to vent tests at different SOC, displayed venting at higher temperatures when the $\mathrm{SOC}$ was decreased. No thermal runaway was observed at any $\mathrm{SOC}$ although cell damage was observed at $100 \%$ SOC, cell swelling was observed at $70 \%$ SOC and no apparent damage was observed at 50\% SOC. 


\section{Acknowledgments}

- Southwest Research Institute

- Mobile Power Solutions 